\title{
El discurso sobre la riqueza del rey en la baja edad Media castellana: aproximación al tesoro de Enrique IV de Castilla como instrumento de propaganda política ${ }^{1}$
}

\author{
The discourse on the wealth of the king in the late Castilian Middle Ages: the \\ treasure of Enrique IV of Castile as an instrument of political propaganda
}

\author{
Pablo Ortego Rico \\ portego@uma.es \\ Universidad de Málaga, España
}

Recepción: 05 Agosto 2020

Aprobación: 24 Noviembre 2020

Publicación: 04 Enero 2021

Cita sugerida: Ortego Rico, P. (2021). El discurso

sobre la riqueza del rey en la baja edad Media castellana: aproximación al tesoro de Enrique IV de Castilla como instrumento de propaganda política. Trabajos y Comunicaciones, (53), e138. https://doi.org/10.24215/23468971e138

\begin{abstract}
Resumen: Estudio del papel asignado a la riqueza y el tesoro de Enrique IV de Castilla como instrumentos de propaganda utilizados en la crítica política y en la legitimación de la oposición al monarca durante su reinado. Asimismo, se analiza el papel desempeñado por ambos elementos en la elaboración de un perfil político y moral del rey que llegaría a formar parte de la memoria historiográfica sobre el monarca elaborada por los cronistas.
\end{abstract}

Palabras clave: Tesoro Real, Riqueza, Memoria Política, Enrique IV de Castilla, siglo XV.

\begin{abstract}
Analysis of the role assigned to the wealth and treasure of Enrique IV of Castile as mechanism of propaganda used in political criticism and in the legitimization of the opposition to the monarch during his reign. Likewise, the role played by both elements in the elaboration of a political and moral profile of the king that would form part of the historiographic memory about the monarch elaborated by the chroniclers is analyzed.
\end{abstract}

Keywords: Royal Treasure, Wealth, Political Memory, Henry IV of Castile, XVth Century.

\section{INTRODUCCIÓN}

La presencia recurrente de elementos hacendístico-fiscales en el debate político castellano se convirtió durante el período bajomedieval en una constante que pone en evidencia la centralidad alcanzada por la creciente disponibilidad de recursos económicos de la monarquía, vinculada a la extensión del poder real entre los siglos XIII y XV a ámbitos cada vez más diversos y amplios, en paralelo a la aplicación de algunos de los principios romanistas inherentes al ius regalium y al desarrollo de fórmulas de negociación del consentimiento fiscal con instituciones representativas como las Cortes que requerían de una legitimación asentada en nuevas formas de retórica política. ${ }^{2}$ De esta forma, dentro del proceso de construcción de una nueva forma de «Estado fiscal», desarrollada fundamentalmente desde la época de Alfonso X (1252-1284) hasta fines del siglo XV, los siguientes fenómenos ocuparían un lugar destacado: el incremento de la capacidad exactiva del poder regio, sustentada en términos doctrinales en la teoría política aristotélica reformulada por la escolástica y en el "derecho común”; la renovación y diversificación de las fuentes de renta de la monarquía, 
extendidas a espacios de la actividad económica cada vez más amplios; los mecanismos de negociación arbitrados con las Cortes o la Iglesia para la concesión de servicios económicos a los reyes justificados en el auxilium al monarca; la extensión de gravámenes al conjunto de los súbditos y naturales del reino ligada a la difusión de una idea de «comunidad política» en la cual el vínculo de «naturaleza» actuaba como disolvente de los nexos personales; y la creciente complejidad de las estructuras de recaudación y distribución de recursos arbitradas. $^{3}$

A medida que se producía esta extensión de las atribuciones fiscales y hacendísticas de la monarquía, muchos escritos de orden político y/o doctrinal también pasaron a incorporar reflexiones sobre la riqueza del príncipe, su capacidad para acumular recursos materiales, la legitimidad de su origen y/o finalidad, o la forma que estos debían adoptar. Gracias a la difusión en Castilla desde el siglo XIII de la materia aristotélica presente en textos sapienciales, de carácter teológico o en la literatura de Speculum principum, dichos escritos contribuyeron a la creación de un perfil ético-político del monarca que establecía ciertos límites teóricos a sus actos en materia hacendístico-fiscal (Ortego Rico, P., 2020ª pp. 298-307). Ello sería particularmente notorio en la caracterización asociada en la literatura política a gobiernos considerados bajo la perspectiva de la tiranía, en los cuales el empobrecimiento de los gobernados y del reino provocado por un uso desmesurado o ilegítimo de las atribuciones fiscales y hacendísticas del monarca se presentaba como una de las acciones que permitían identificar su actuación como tiránica. Así lo resaltaban textos tan representativos del siglo XIII como la Segunda Partida o el Libro de los cien capitulos, o tratados y compendios políticos posteriores que actualizaban y ampliaban la reflexión sobre la tiranía, como la Avisaçión de la dignidad real o la Suma de la Política de Rodrigo Sánchez de Arévalo, entre otros (Nieto Soria, J. M., 2005, p.75; Ortego Rico, P., 2009, pp.134-136). ${ }^{4}$

De forma paralela, estos argumentos doctrinales tuvieron en Castilla un campo de aplicación específico en la lucha por el poder desarrollada durante el período bajomedieval, salpicado de continuas crisis de legitimidad y conflictos, en la medida en que contribuían a dar soporte teórico a acciones concretas, pero también porque su difusión a partir de mecanismos de propaganda podía facilitar la conexión con aquellos colectivos afectados por las prerrogativas fiscales asumidas por el rey. Por lo tanto, el discurso hacendísticofiscal podía influir como instrumento de adhesión y movilización política en la creación y difusión de corrientes de «opinión pública» ${ }^{5}$ pero también se encontraba muy presente en los procesos de conformación de una «memoria historiográfica» sobre la acción del gobernante. ${ }^{6}$ En definitiva, apelar al comportamiento hacendístico-fiscal del monarca podía amplificar la capacidad de aquellas instancias políticas que recurrían a estos argumentos para suscitar apoyos o legitimar sus actos en la medida en que los elementos de crítica o valoración positiva formulados, pese a su deformación o exageración intencional, remitían a realidades reconocibles que afectaban a amplios sectores socio-políticos, habida cuenta de la amplia extensión alcanzada por la capacidad exactiva del poder real en los siglos bajomedievales.

Además de las posibilidades de conexión con los receptores del mensaje transmitido, los argumentos hacendístico-fiscales también facilitaban un nexo con algunos de los fundamentos doctrinales que daban cuerpo a los arquetipos del buen gobernante, y del tirano como su reverso «en negativo», elaborados por la reflexión teórica. De esta forma resultaban doblemente eficaces al proyectar una determinada forma de discurso ideológico sobre amplias capas sociales, susceptible de ser asimilado bajo fórmulas en ocasiones simplificadas.

Así había sucedido en el caso de Pedro I (1350-1369), cuyo perfil tiránico recreado a fines del siglo XIV por la labor cronística del Canciller Pero López de Ayala incorporaba como muestra de codicia su especial apego por la acumulación desordenada de riquezas materiales a costa del empobrecimiento de sus súbditos y del reino, evidenciado en la conformación de un tesoro que le habría acompañado en sus desplazamientos durante la guerra civil sostenida con su hermanastro Enrique II (1366-1369). ${ }^{7}$ Dicha formulación, presentada por Ayala como soporte de la fabricación de una memoria negativa del monarca, 
ya había sido explicitada como parte de una crítica concreta, coetánea al conflicto civil, que contribuía a deslegitimar los actos del monarca depuesto. Por ejemplo, en el ordenamiento de las Cortes de Burgos convocadas por Enrique II en 1367 ya se ligaba la actuación de Pedro I como tirano con la acusación de empobrecer y despoblar la tierra mediante la imposición de grandes tributos y pechos sobre el reino ${ }^{8}$, recogida de manera genérica en el catálogo de "prácticas tiránicas" incluido en la Segunda Partida (Nieto Soria, J. M., 2005, p. 75).

Más adelante, los elementos hacendístico-fiscales también estuvieron muy presentes en la caracterización como tirano del Condestable don Álvaro de Luna, el gran privado de Juan II, a partir de las acusaciones vertidas desde 1425 por sus enemigos, trasladadas desde al menos 1449 a movimientos urbanos de contestación política como la revuelta anticonversa desarrollada en Toledo. Dichas acusaciones -que concretaban la condición tiránica asignada por primera vez en Castilla a un privado regio, en lugar de al monarca- remitían a acciones como el establecimiento de exacciones injustas, la malversación y apropiación de bienes y rentas pertenecientes a la Corona, el empobrecimiento del reino motivado por la solicitud de servicios económicos desmesurados -cuya gestión se habría situado además en manos de agentes afines y herejes-, y al enriquecimiento personal logrado por el privado regio a partir de decisiones de índole hacendístico-fiscal que formaban parte, según sus oponentes, de la suplantación de las funciones gubernativas y prerrogativas del rey. Así se había hecho constar en escritos tan relevantes en el proceso de conformación de una imagen, «opinión nobiliaria», y en último término de una «opinión popular», contrarias al Condestable, como la carta remitida en 1425 por Alfonso V de Aragón al señor de Pedraza Pedro Núñez de Herrera, el memorial anti-lunista enviado por algunos grandes a Juan II en 1440 o la Soplicación e requerimiento mandada al rey por Pero Sarmiento en el contexto de la revuelta toledana de 1449 (Nieto Soria, J. M., 2017, pp. 493-494; Ortego Rico, P., 2015, pp. 46-94).

\section{LA CRÍTICA HACENDÍSTICO-FISCAL CONTRA ENRIQUE IV COMO ELEMENTO PROPAGANDÍSTICO}

Por lo tanto, a mediados del siglo XV, el recurso a argumentos hacendístico-fiscales en la legitimación de la lucha por el poder desplegada en torno a la monarquía castellana respondía a una práctica consolidada y recurrente que también se hizo extensible a un reinado tan conflictivo como el de Enrique IV (1454-1474) una vez desatada la crisis que culminaría con la deposición en efigie del monarca en junio de 1465 por una parte de la nobleza y el episcopado castellano. ${ }^{9}$ Dichos elementos de crítica hacendístico-fiscal, si bien quizás no se situaban en el centro de las acusaciones más graves y con mayor potencial difamatorio lanzadas contra el rey por sus opositores (negación de su paternidad sobre la princesa Juana, acusación de favorecer a gentes indignas de «bajo estado»y «oscuro linaje», homosexualidad, impotencia, filoislamismo, protección de herejes, entre otras ${ }^{10}$ ) contribuían a trasladar una idea de incompetencia en el ejercicio del poder y dejación de funciones que atentaba contra elementos que todo buen gobernante estaba obligado a preservar, como la justicia, el «bien común» de la res publica o la fe católica. Con ello podían legitimarse las formas de oposición desarrolladas por aquellas instancias, por ejemplo la nobleza del reino, que se habían arrogado la representación de la «comunidad política» ante lo que se consideraban actuaciones injustas que incurrían en un defecto de jurisdiccin, según la formulación sobre el «derecho de resistencia» realizada pocos años antes por el bachiller Marcos García de Mora a colación de la revuelta toledana de 1449 (Nieto Soria, J. M., 2005, p. 84).

Antes de consumarse la ruptura política en 1464, la crítica al enriquecimiento del rey mediante instrumentos reprobables ya se habría hecho manifiesta en una conocida carta supuestamente enviada en julio de 1462 por Diego de Valera al monarca. En su escrito, Valera enumeraba todo un conjunto de prácticas contrarias al buen gobierno que habrían despertado el descontento de los tres estados del reino, antes de 
aconsejar al rey su enmienda recurriendo a un discurso histórico que incorporaba a modo de exemplum la narración de diferentes episodios de deposición regia justificados en causas mucho más leves a las ahora denunciadas. Cabe señalar que, en lo que se refiere al origen ilegítimo de la riqueza del rey, entre las prácticas denunciadas por Valera ya se hacía mención expresa a la entrega de dignidades eclesiásticas y seglares a hombres indignos, "e lo que peor es, que muchos afirman que se dan por dineros" (de Valera, D., 1878, pp. 17-20). De esta forma, las prácticas venales denunciadas, a las que se asignaba presunción de veracidad en virtud de un supuesto conocimiento colectivo o común, quedaban ligadas al ascenso político de gentes inadecuadas patrocinado por Enrique IV, que formaría parte de los elementos de crítica contra el monarca utilizados de forma más recurrente a partir de este momento.

Mucho más explícito en sus críticas en materia económica y fiscal se mostraba un texto tan representativo en la evolución del conflicto político del reinado enriqueño como el memorial remitido al monarca desde Burgos el 28 de septiembre de 1464 por los nobles alzados contra el rey, capitaneados por el marqués de Villena, cuya difusión supuso un punto de inflexión en su actividad opositora. Erigiéndose en representantes de los tres estados del reino, los nobles lanzaban graves acusaciones contra la acción gubernativa del monarca, con el objetivo de presionarle mediante la creación de un estado de «opinión pública» favorable a sus objetivos. Entre estas acusaciones figuraba la siguiente:

Otrosí los grandes tesoros que vuestra alteza allegó así de las rentas de vuestros regnos como de pedidos e monedas e de otras extorsiones que los oficiales de vuestra señoría a gran cargo de vuestra conciencia e suya de ellos a vuestra altesa procuraron, como de la santa cruzada o del susidio que de los Santos Padres vuestra señoría ganó so color de faser la guerra á los moros; si aquellos fueron gastados e despendidos en servicio de Dios e en, defensión de la fe e en administrar la justicia del regno e del bien de la república del, vuestra señoría e todos los tres estados de vuestros regnos lo conoscen (Memorias de don Enrique IV 1835-1913: doc. XCVII, 330).

Con esta denuncia se traía a un primer plano la ilegitimidad del tesoro conformado por el rey en función de su desajuste con algunos de los principios señalados tradicionalmente por la tratadística política acerca del origen y finalidad de la riqueza del príncipe. Según esta visión, podía deducirse implícitamente que el papel reservado al monarca era el de un mero administrador de los recursos económicos concedidos para la consecución de fines legítimos (el servicio a Dios, la defensa de la fe, la justicia del reino y el bien de la res publica) que no habían sido convenientemente atendidos. Además, la riqueza enriqueña incurría en un déficit de legitimidad, pues su origen se situaba, en algunos casos, en presiones ejercidas por sus oficiales, y en otros caso del subsidio y la cruzada - había sido obtenida con engaños, simulando su empleo en una finalidad justa y legítima (la guerra santa) como parte de una operación de propaganda denunciada por los nobles.

Esta imagen del monarca como administrador condicionado de las rentas del reino en favor del "bien común” contaba con un largo recorrido en la tratadística política de la Europa Occidental -de la que es buena muestra un texto tan difundido y glosado como el De regimine principum de Egidio Romano- y llevaba asociada de manera implícita una despersonalización entre los bienes del príncipe, por un lado, y los bienes administrados en favor de la comunidad política, por otro. ${ }^{11}$

Sirva como ejemplo de la extensión durante la primera mitad del siglo XV de estas ideas, que terminaron convirtiéndose en lugar común, la reflexión incorporada en el anónimo Libro de Gracián, un texto posterior a 1433 vinculado al entorno político contrario a don Álvaro de Luna (Satorre, J. J., 1980, pp. 165-210). En este escrito se justificaba la entrega de rentas a los príncipes como retribución ordenada por el pueblo para compensar su "grand cargo e trabajo" y garantizar su mantenimiento. Con ello se situaban los orígenes del hecho fiscal en una concesión realizada por los gobernados, legitimada a partir de la función en favor de la comunidad otorgada al príncipe. Esta concepción «ascendente» de la fiscalidad condicionaba la entrega de rentas al cumplimiento por parte del gobernante de todo un conjunto de requisitos -muy similares a los presentes en el memorial de los nobles de 1464- que definían los límites de una «fiscalidad virtuosa» atendiendo a su finalidad y forma. Dichos requisitos pasaban por el mantenimiento del servicio a Dios "faziendo al pueblo que lo amasen e temiesen, e buenas costunbres pusiesen e mantoviesen"; el empleo de 
los fondos percibidos en el sostenimiento de los oficiales que le auxiliaban en la aplicación de la justicia; y el gasto de los recursos de manera ordenada, con moderación, guardando la justicia, y evitando dañar o disipar al pueblo tomando "de los omnes lo que avían contra su voluntad", mostrando una preferencia por la contención en el gasto en caso de que las rentas otorgadas no fuesen suficientes en algún momento (Satorre, J. J., 1981-1983, p. 107).

Al margen del posible nexo entre las reclamaciones hacendístico-fiscales planteadas al rey en septiembre de 1464 y los fundamentos doctrinales que las apoyaban, presentes en muchos textos coetáneos, estos elementos de crítica se verían posteriormente amplificados hasta el punto de convertirse en un tópico utilizado para justificar la retirada de la obediencia al monarca y reclamar la adhesión política a los sublevados en el contexto posterior a la deposición en efigie del rey realizada en Ávila el 5 de junio de 1465.

Desde el punto de vista de la propaganda de tintes más o menos «populares», el recurso al mal uso dado al tesoro y las riquezas de Enrique IV, y los perniciosos efectos de su política fiscal sobre el reino, se trasladaron rápidamente a composiciones satíricas, como las famosas Coplas de Mingo Revulgo, alegoría pastoril presentada en forma de diálogo entre el pastor Mingo Revulgo y el profeta Gil Arrivato en el que se reprocha la conducta del mayoral Candaulo -trasunto de Enrique IV-, compuesta en una fecha fijada entre la deposición del monarca realizada en junio de 1465, y fines de 1467 o comienzos de 1468 (Paolini, D., 2008, pp. 34-39). En este sentido, la copla IX, incorporaría -según la interpretación realizada por D. Paolini (2008, pp. 37-39 y 184) - una crítica velada al contador mayor Diego Arias Dávila, calificado como "lobo carnicero por medio de las manadas", lo que concuerda con el papel de depredación financiera que se le asigna en las crónicas contrarias a Enrique IV. Por su parte, la copla X parece afilar su crítica contra los negativos efectos derivados de la mala distribución dada a los tributos pagados al rey en concepto de "soldada", entregados a gentes ruines. ${ }^{12}$

La misma utilización del tesoro y la política fiscal del monarca como elemento de crítica política, aunque focalizada en la conformación de una «opinión nobiliaria» contraria al rey, se incluye en la carta enviada por los alfonsinos al conde de Arcos don Juan Ponce de León desde Valladolid el 25 de septiembre de 1465 instándole a que se mantuviese al servicio del rey Alfonso. En ella se insiste en la ilegitimidad del tesoro acumulado por Enrique IV en Segovia, gastado de forma casi íntegra para solventar los graves apuros económicos por los que estaría atravesando el monarca tras su deposición. Al mismo tiempo, también se profundiza en elementos de crítica hacendística-fiscal ya formulados con anterioridad: adulteración y falsificación de la moneda; ${ }^{13}$ cobro de «pedidos» $\mathrm{y}$ «monedas» concedidos por las Cortes, pagados por gentes cuya condición miserable y pobre evidenciaba, por un lado, el desajuste de la exacción al principio de moderación y, por otro, el empobrecimiento del reino que de ello se seguía; malversación en los recursos procedentes de la cruzada y el subsidio; cohecho en la administración de la justicia y venalidad en la provisión de los oficios encargados de gobernar y administrar las ciudades del reino (corregidores, regidores, alcaldes, jurados, escribanos). Al catálogo de malas prácticas se sumaba un argumento religioso que reforzaba el discurso elaborado para persuadir al noble de la necesidad de abandonar a un rey carente en aquel momento de recursos económicos para continuar la guerra: la ilegitimidad en el origen del tesoro acumulado por el monarca había sido castigada por Dios, de manera que su gasto no había redundado en "ningund provecho e utilidad suya". ${ }^{14}$

La presencia del tesoro en el argumentario mostrado ante el Pontífice, como instancia con capacidad para legitimar la deposición del rey llevada a cabo por una parte de la nobleza y episcopado castellano, también contribuía a perfilar el comportamiento tiránico de Enrique IV. En este sentido, la carta remitida por la ciudad de Sevilla al papa Paulo II el 9 de diciembre de 1465 -transcrita en la Gesta Hispaniensia de Alfonso de Palencia y quizás redactada por el propio cronista- en la que se hacía partícipe al Pontífice romano de las causas que habían motivado el alzamiento como monarca del príncipe Alfonso, da un paso más allá en el uso discursivo de las riquezas y del tesoro enriqueño, al contraponer las esperanzas iniciales que había concitado el acceso de Enrique IV al trono con los resultados de un mal gobierno considerado bajo la perspectiva de 
la tiranía y solo explicable como instrumento utilizado por Dios para castigar los pecados del pueblo (de Palencia, A., 1999, p. 310-311).

Tras poner de manifiesto los medios de gobierno que el monarca podría haber utilizado para vencer a sus enemigos y regir con justicia el reino -la carta señala, por ejemplo, que "sus rentas eran abundantes" al comienzo de su reinado-, a continuación se plantea el uso dado a los recursos económicos solicitados por el rey al reino, bajo pretexto de sufragar los gastos de las campañas contra Granada, en el enriquecimiento de los infieles. ${ }^{15}$ Con ello, la política fiscal enriqueña, transmutada en robo al pueblo, no solo se enjuiciaba en términos de ilegitimidad sino que también servía para justificar la calificación del monarca depuesto como “azote de Dios, enemigo de la fe y amigo de los moros" asociada a su condición tiránica.

De igual manera, según la misma carta, la riqueza del rey habría cumplido otras funciones contrarias al buen regimiento del reino: en primer lugar, "los tesoros abundantes de Enrique" habían limitado la capacidad de mostrar oposición ante una situación de tiranía que solo la intervención divina, prestando su favor a la nobleza que apoyaba al príncipe don Alfonso, habría alterado; además, tras su deposición, los tesoros de Enrique IV habrían quedado disipados al haberse desperdiciado de forma inútil "sin eficacia alguna para curar su ruina" en el pago de la multitud de soldados que le acompañaba "atraída no por el cariño sino por el dinero, porque agotadas sus riquezas ya lo está abandonando". Con ello se destacaba el mal uso dado por el monarca a la riqueza que acumulaba con el objetivo de anudar unas relaciones de «falsa fidelidad» desligadas del vínculo «amoroso» que debía primar en la obediencia y fidelidad mostrada por los súbditos a un rey justo y que, como «emoción» recurrente en la retórica política de la época, garantizaba la durabilidad y conservación del poder del monarca (Bermejo Cabrero, J. L., 1973).

Finalmente, el uso de la riqueza y el tesoro del rey en el debate político coetáneo, también tuvo eco en algunos de los textos doctrinales elaborados durante el período 1465-1468. Tal es el caso de las reflexiones incorporadas por Pedro de Chinchilla en su Exhortación o información de buena y sana doctrina, dirigida en mayo de 1467 a modo de speculum principum al joven rey Alfonso para su formación. Al abordar las características y comportamientos asociados a la puesta en práctica de la virtudes de la liberalidad, magnificencia y magnanimidad, su autor incorpora algunas muestras del empleo virtuoso y del mal uso dado a las riquezas, que podían ofrecer una lectura implícita de los defectos político-morales atribuidos tanto a Enrique IV como a su círculo de servidores, fácilmente reconocibles por el lector coetáneo, lo que concedía al texto una función relevante en el afianzamiento de la legitimidad alfonsina. De esta forma, siguiendo la doctrina aristotélica, Pedro de Chinchilla afirmaba que "el que es liberal en guardar e conservar sus rentas, para liberalmente gastar e non para conservar ni atesorar, que es especia d'escaseza, usará de todo liberalmente". Del mismo modo, el discurso contrario a la codicia enunciado señalaba que "los avarientos tanto aman los bienes temporales de fuera que piensan qu'el mayor bien de todos los bienes es conservar e alegallos", lo que en el contexto del momento era susceptible de ser interpretado -como otras partes del mismo texto- como una referencia velada a uno de los elementos de crítica política formulados contra el monarca depuesto (Nogales Rincón, D., 2017, pp. 235-242).

Estos ejemplos ponen de manifiesto que el discurso sobre la riqueza del rey presente en la propaganda anti-enriqueña coetánea a los hechos denunciados y difundido en forma de memoriales, proclamas políticas, misivas o textos doctrinales -entre otros vehículos de comunicación ${ }^{16}$ - reprobaba con particular énfasis la tesaurización de recursos llevada a cabo por el monarca. Desde esta perspectiva, la conformación de un abundante tesoro era resultado de prácticas que además resaltaban la falta de liberalidad del rey, como virtud esencial del buen gobernante derivada de la virtud cardinal de la justicia y aplicada en acciones referidas a la riqueza y el dinero, ${ }^{17}$ cuando no su actuación contraria a Dios y la Iglesia evidenciada en el supuesto uso de esta riqueza en favor de los enemigos de la fe. Estas denuncias contribuyeron a la caracterización de Enrique IV, en unas ocasiones como tirano -tal y como evidencia la misiva enviada al papa por la ciudad de Sevilla en 1465-, y en otras como rex inutilis o incompetente, en la medida en que algunas de las acciones emanadas de la potestad regia consideradas como contrarias al reino y a la fe-por ejemplo aquellas referidas al campo 
hacendístico-fiscal, aunque no solo- se presentaban como consecuencia de decisiones adoptadas, bien por agentes políticos en los cuales habría delegado el uso de sus funciones, o bien por el propio monarca siguiendo su consejo (Beceiro Pita, I., 2002; Nieto Soria, J. M., 2005).

\section{3. «MEMORIA HISTORIOGRÁFICA» Y DISCURSO CRONÍSTICO SOBRE LA RIQUEZA DE ENRIQUE IV}

La abundante cronística sobre el reinado de Enrique IV reelaboraría posteriormente muchas de las ideas contrarias a la acción gubernativa del monarca puestas en circulación por sus opositores desde 1464, entre ellas las asociadas a la riqueza y el tesoro del rey. De esta forma, las valoraciones hacendístico-fiscales aportadas por los cronistas, además de perfilar en términos políticos y morales la imagen del rey, contribuyeron a crear una «memoria historiográfica» del monarca. Dicha memoria era susceptible de actualizar a posteriori su reinado con fines de legitimación o aleccionadores, aunque en este caso se haría particularmente notorio el "conflicto de memorias" a tenor de las visiones divergentes del reinado aportadas por los diferentes cronistas mediante la diferente selección de «elementos memorables» realizada y especialmente de su valoración ${ }^{18}$. No obstante, como parte de la imagen y «memoria común» del monarca, la mayor parte de los autores resaltaba de manera tópica como rasgo distintivo la gran riqueza que llegó a acumular Enrique IV, especialmente durante los primeros años de su reinado (Triano Milán, J. M., 2018, pp. 213-214). Su plasmación física más evidente habría sido la conformación de un abundante tesoro custodiado en el alcázar de Segovia, ${ }^{19}$ de cuya composición dan fe los testimonios documentales que se refieren al mismo y otros referentes a las joyas, tapices y objetos adscritos a la cámara del monarca, estudiados por M.. Ladero Quesada. ${ }^{20}$

En efecto, tal y como denunciaba el memorial nobiliario de septiembre de 1464, algunos de estos recursos tesaurizados procedían de los servicios económicos en forma de «pedidos» y «monedas» concedidos por las Cortes y desviados de la finalidad para la que habían sido otorgados por el reino ${ }^{21}$. Un total de 25.475 .000 mrs correspondientes a la recaudación del «pedido»y «monedas» aprobado por las Cortes para el bienio 1455-1456 fueron recibidos por el contador mayor del rey Diego Arias Dávila. Dentro de esta elevada suma se incluían cantidades no especificadas de maravedíes "que se troxieron a los depósitos de Escalona e de Segovia" hasta el 1 de enero de 1458, según indica un sumario del ingreso y gasto de estos recursos. ${ }^{22}$ Lo mismo sugieren las entregas de dinero líquido procedentes del servicio aprobado por las Cortes de 1462 con la finalidad teórica de financiar las campañas del rey contra Granada, incluidas en el cargo o ingreso de Diego Arias Dávila y situadas bajo la custodia del camarero del rey Juan de Tordesillas en el alcázar de Segovia (Ladero Quesada, M. A., 1988, p. 278). También está constatada la recepción por parte de Arias Dávila de cantidades procedentes del subsidio y la cruzada autorizados en 1455 por el papa Calixto III, recaudado a partir de 1457, así como la desviación de algunos de estos fondos en fines alejados de la guerra contra Granada que había motivado su concesión. ${ }^{23}$

Por lo tanto, los datos sobre el tesoro enriqueño aportados por las crónicas responden a una realidad comprobable en términos documentales, y plenamente notoria a ojos de los contemporáneos del monarca. Sin embargo, la calificación ético-política de estas riquezas -favorable o desfavorable- realizada posteriormente por los cronistas, y su proyección sobre el regimiento del reino y la imagen del monarca como gobernante, diferían en la medida en que su inserción en los diferentes relatos y su amalgama con argumentos doctrinales respondía a los objetivos propagandísticos y de legitimación perseguidos por cada autor a la hora de conformar posteriormente la memoria de Enrique IV. De esta forma, los rasgos positivos/ negativos otorgados al tesoro y la riqueza enriqueños fueron emplearon como soporte del discurso elaborado en torno a las virtudes/vicios asignados al rey. 


\subsection{Fama, liberalidad y magnanimidad: la imagen positiva de la riqueza del rey}

La obra de Diego Enríquez del Castillo, como paradigma de la cronística favorable al monarca, señala en el retrato físico y psicológico sobre Enrique IV que el rey "hera señor de grandes tesoros, amigo y allegador de aquellos, más por fama que cobdiçia” (Enríquez del Castillo, D., 1994, p. 134). Por lo tanto, para este autor el afán tesaurizador del monarca tenía connotaciones positivas en la medida en que actuaba, en primer lugar, como instrumento comunicativo útil en términos políticos a la hora de construir y difundir de manera intencional una imagen de buena reputación, notoriedad y prestigio en el ámbito público ${ }^{24}$. No era la primera vez que la acumulación de riquezas era considerada en términos positivos como parte de la memoria de un monarca castellano. Tanto los ordenamientos de las Cortes de 1440 y 1447, como las Generaciones y semblanzas de Fernán Pérez de Guzmán (ca. 1450-1455), entre otros textos, ya habían incluido la capacidad de tesaurización de Enrique III entre los rasgos positivos del rey señalados como modelo de conducta y buen gobierno (Ortego Rico, P., 2020a, pp. 312-316).

Por otra parte, el mismo cronista hace partícipe al lector de la imagen prestigiosa de Enrique IV durante sus primeros años de gobierno, vinculada a la posesión de grandes tesoros, pero también al enriquecimiento logrado de manera paralela para el reino que gobernaba, al narrar los acontecimientos sucedidos en 1462 - considerado como el punto culminante del reinado enriqueño-, tras la llegada del monarca a Almazán. Allí recibió sendas embajadas catalana y francesa, la primera para ofrecerle la obediencia del Principado de Cataluña y la segunda para acordar vistas en Fuenterrabía con Luis XI. En este contexto narrativo, Enríquez del Castillo refleja el sentimiento de alegría del que participaba el rey, al verse colmado con todo un conjunto de atributos que evidenciaban su condición como buen gobernante

"ca se veya puesto en más alta cunbre de sublime estado, que nunca estuvo rrey de sus antepasados de grandes tienpos hasta él, poderoso, temido, quieto, muy enjoyado, no solamente poseedor de grandes thesoros, más señor de los rricos, porque todos en sus rreynos estavan enrriqueçidos y nunca despechados" (Enríquez del Castillo, D., 1994, p. 199)

Con estas referencias, el cronista desligaba la riqueza acumulada y exhibida por el monarca de cualquier consideración pecaminosa o alejada de la práctica de la virtud, situándose en la estela de un discurso, presente desde el siglo XIII en la tratadística política, moral y religiosa del Occidente europeo, y en textos castellanos del siglo XV como la Suma de la política de Rodrigo Sánchez de Arévalo o El libro de las veynte cartas e quistiones de Fernando de la Torre (1449), que revalorizaban la riqueza del príncipe y su capacidad para acumular y exhibir tesoros y riquezas (Boureau, A., 2006, pp. 265-266; Scordia, L., 2005, pp. 337-339). ${ }^{25}$ Dicha revalorización solo era planteada siempre y cuando el origen, finalidad, medida y forma de la riqueza acumulada se ajustara al paradigma de «imposición virtuosa» configurado $^{26}$ y a la ética definida por el aristotelismo político. En lo que se refiere a las acciones relativas al dinero y la riqueza, este comportamiento ético estaba basado en la práctica de la liberalidad, la magnanimidad y la magnificencia como virtudes emanadas de la justicia, en el caso de la primera, y de la fortaleza, en el caso de las dos segundas (Díez Yáñez, M., 2014, p. 453), y en la aplicación del principio de moderación. Dichos elementos regulaban situaciones extremas de exceso o defecto limitadoras del «bien común», como objetivo final de la acción gubernativa. ${ }^{27}$

Por lo tanto, en el perfil de Enrique IV recreado por Enríquez del Castillo la posesión de riquezas por parte del monarca se presentaba como un elemento plenamente virtuoso. No solo se ligaba a una imagen de fortaleza política y prestigio del rey, de la que también participaba un reino próspero en términos económicos. La riqueza enriqueña también se vinculaba a la puesta en práctica de la virtud de la liberalidad, reflejada en la concesión de abundantes franquezas realizada por el monarca "mientras estuvo prosperado". ${ }^{28}$ Además, tal y como enfatizaba el cronista en la apología del rey incorporada al final de su obra, Enrique IV se presentaba como paradigma de comportamiento mesurado, en la medida en que la disponibilidad de recursos -como 
sus "sobradas rriquezas" - ligados al ejercicio del poder, no le había llevado a incurrir en el vicio de la avaricia (Enríquez del Castillo, D., 1994, p. 399).

Esta «apología de la liberalidad»-término medio aristotélico entre la codicia y la prodigalidad- volvía a explicitarse en el capítulo dedicado por el cronista a "las cosas eçelentes que el rrey dixo y hiso como prínçipe magnánimo" antes del inicio de la crisis que marcaría la segunda mitad de su reinado. En dicho capítulo se recrea el hipotético diálogo sostenido entre el contador mayor Diego Arias Dávila y el monarca a cuenta de los elevados gastos realizados para el pago de sueldos, acostamientos, ayudas de costa y mercedes a los hijos de los nobles, notables y otras "generosas personas" presentes en la corte (Enríquez del Castillo, D., 1994, pp. 162-164). La incorporación de este fragmento respondía al objetivo del cronista por contrarrestar desde un punto de vista doctrinal las críticas vertidas posteriormente contra el rey en las cuales se le acusaba de disipar su patrimonio y el de la Corona mediante la concesión indiscriminada de mercedes, especialmente a hombres considerados indignos. ${ }^{29}$ No en vano, en la mencionada apología final sobre Enrique IV, Enríquez del Castillo reiteraba la imagen del rey como «señor de grandes tesoros», señalando a fin de exculparle de responsabilidad en el fracaso de su reinado y como advertencia aleccionadora a futuros gobernantes, que su empobrecimiento - como el resto de sus desdichas- respondía a la ingratitud y traición de los suyos que, "rresçibiendo merçedes, se tornaron peores", y no a las iniciativas de un monarca franco que habría sido capaz de mantener intactas sus virtudes como gobernante pese al cúmulo de adversidades sobrevenidas a las que habría tenido que enfrentarse (Enríquez del Castillo, D., 1994, p. 399). ${ }^{30}$

Por ello, frente a la consideración, puesta en boca de Diego Arias Dávila, de los dispendios del monarca como "eçesivos gastos y sin provecho" con los que se gratificaba a "gentes que ni syrven, ni lo mereçen", y a la recomendación de limitar los desembolsos únicamente a aquellos hombres que prestaban sus servicios al rey, Enrique IV respondía al contador mayor con un excurso teñido de doctrina política en el que se apelaba al comportamiento que como titular de la dignidad real debía observar para cumplir con la misión encomendada por Dios. Dicho comportamiento, que se planteaba como modelo de conducta para los gobernados y situaba a la realeza como espejo en el que debían mirarse los súbditos al poner en práctica la virtud, debía estar presidido por la búsqueda del "bien universal de todos" y responder a "la utilidad de muchos" como fines últimos globalizadores fijados por la divinidad. Una conducta opuesta a tales principios, definida en el caso objeto de controversia por el establecimiento de límites a la distribución de la riqueza contrarios a la magnanimidad y la liberalidad/franqueza como virtudes esenciales del príncipe, podía considerarse como una forma de tiranía o como "cobdiçia desordenada" en lugar de "señal de vondad". Máxime si se tiene en cuenta el papel reservado a la franqueza en el juego de las relaciones políticas establecidas en torno a la monarquía, entendidas en términos emocionales. De esta forma, un comportamiento liberal reforzaba la "amistad" del buen monarca con sus súbditos, facilitando en unos casos su servicio y evitando en otros su dedicación al robo o su muerte sin honra.

No obstante, existían límites a la distribución de la riqueza asociada a la magnanimidad regia, entendida como "perder y dar" y no como "dar y perder" en función de su nexo con una generosidad necesaria y completamente desprendida, ${ }^{31}$ que encontraba justificación teológica en pasajes bíblicos. ${ }^{32}$ Dichos límites estaban marcados por la imposibilidad de incrementar los tributos justamente percibidos para atender a las necesidades asociadas a la puesta en práctica de la virtud. Tal y como señalaba el monarca en su respuesta a Diego Arias Dávila, "tanpoco me plaze que mis pueblos por esto sean despechados, ni les ynpongan tributos, que, pues, por la graçia de Dios, que me lo dió, tengo rrentas y tesoros para ello, gran synrrazón sería fatigallos o pedilles más de lo que justamente deven" (Enríquez del Castillo, D., 1994, p. 163). Es aquí donde la riqueza del príncipe y las rentas que percibía, legitimadas en un origen divino que resaltaba la fundamentación religiosa de la tributación al gobernante presente, por ejemplo, en los textos de San Pablo, ${ }^{33}$ desempeñaban un papel político esencial al sostener la generosidad y magnanimidad del rey sin lesionar los recursos económicos de sus súbditos mediante el recurso a impuestos gravosos, y con ello la búsqueda del «bien común» que debía presidir su acción gubernativa. Ello suponía alcanzar un punto de equilibrio entre los ingresos privativos del 
monarca -sujetos al principio aristotélico de moderación- y los gastos inherentes a su responsabilidad como agente distribuidor de la riqueza que como gobernante administraba, puesta necesariamente en circulación.

La imagen positiva de la riqueza de Enrique IV como fuente de poder y prestigio tendría ecos posteriores, pese a la amplia difusión del discurso contrario al monarca sobre el cual se construyó en buena medida la legitimidad de los derechos de Isabel I al trono. No obstante, la incorporación en algunas crónicas del discurso sobre la opulencia del rey como manifestación de poder, pese a quedar desvinculada de elementos de crítica moral, realmente servía para construir un relato deslegitimador de su acción política al establecer un claro contraste entre la bonanza económica heredada de su padre y la situación de postración en la que habría dejado el reino a su muerte.

Es el caso de la Crónica incompleta de los Reyes Católicos que, en su descripción de Enrique IV, enfatiza de manera hiperbólica la excelente herencia obtenida por el monarca al acceder al trono: el rey habría recibido "vn Reyno y Reynos tan ricos y paçificos, como se cree ningund rey despues del fundamento del mundo tuuo en España". De la misma manera, el anónimo cronista hace constar que el monarca "fue tan rico de tesoros, perlas y piedras preçiosas, que ninguno más rico en el tiempo de él en la grandeza del mundo hallauan” y resalta que "como las rentas de sus Reynos eran grandes y los thesoros mayores, avnque sus gastos eran demasiados, con la sobra de sus riquezas ninguna costa sentia”. Una Hacienda saneada, pese a la crítica deslizada sobre la elevada cuantía de los dispendios del monarca, era el mejor emblema del poder del rey, cuya continuidad no obstante se habría visto frustrada. Según el cronista, de haber logrado en los primeros años de su gobierno el consenso de los grandes, Enrique IV habría podido realizar grandes ganancias territoriales y conquistas -especialmente frente a los musulmanes-, limitadas además por cierta falta de ambición política fundada precisamente en su gran poder y riqueza, pues "él, tan grand prinçipe se hallaua, que ser mayor non le ponia codiçia” (Puyol, J., 1934, pp. 48-49).

Sin embargo, la visión desencantada aportada en este fragmento por la Crónica incompleta de los Reyes Católicos se tornaba inmediatamente en crítica furibunda a las medidas adoptadas por Enrique IV contrarias al bien del reino, que debía de haber conservado como procuraba un padre el bien para sus hijos. Su deposición en efigie en junio de 1465, la proclamación de su hermano Alfonso como monarca, y la división del reino en dos obediencias habrían puesto al rey "en tan grand estrecho, que de ser el mayor prinçipe del mundo vino a ser el más menguado y menor dél". En aquellas circunstancias, el monarca habría tratado deliberadamente de fomentar la destrucción de Castilla pensando en la posibilidad de que, ante la falta de descendencia -pues se descartaba su paternidad sobre la infanta Juana- don Alfonso la heredase y "con tantas nesçeçidades la ouiese, que muy pobre rey se hallase".

Para consumar esta suerte de "venganza" póstuma contra su hermanastro, Enrique IV no habría dudado en enajenar ciudades, villas, lugares y fortalezas a favor de los grandes nobles, en conceder mercedes "largamente de sus thesoros" y en entregar de manera desordenada cantidades de dinero en forma de juro cuya cuantía excedía el rendimiento de las rentas sobre los cuales se situaban, transmutando la virtud de la franqueza en el vicio de la prodigalidad. Con ello -concluía el autor de la Crónica incompleta- el rey "non solamente fue franco, mas el más desordenado pródigo que pienso [que] en ninguna verdadera estoria se halle escripto". Según esta visión denigratoria, la prodigalidad del rey había incrementado el poder de los grandes a costa de la enajenación del reino "tanto que ya él non tenia en todo el Reyno apenas blanca de renta, y él y los suyos del tesoro y de diuersas impusiçiones, pedidos y monedas comian” (Puyol, J., 1934, pp. 60-61). De esta forma, se planteaba la merma de recursos de monarca en unos términos discursivos similares a los explicitados, por ejemplo, en la carta remitida por los alfonsinos al conde de Arcos en 1465, según ha quedado señalado anteriormente.

Pese a todo, esta imagen contrapuesta del monarca -el que podía haber sido y el que terminó siendoutilizada en última instancia para legitimar la posición de Isabel I como sucesora ante los efectos del mal gobierno enriqueño, no incluye una valoración negativa del tesoro y riquezas de Enrique IV. Tampoco lo hace la Crónica anónima castellana que cubre el período 1454-1536, quizás identificada con la segunda parte 
del Catálogo real de los reyes de Castilla de Gonzalo Fernández de Oviedo. En esta obra se reivindica de forma abierta una memoria positiva del reinado enriqueño, trasladando al lector todo un conjunto de virtudes asociadas a prácticas características del buen gobierno, entre las cuales se destacaban las relacionadas con el campo hacendístico-fiscal. Así, su autor precisaba que "el Rey don Enrrique ayuntó grandes thesoros, aunque no ponía tantos tributos y pechos a sus súbditos como el rey don Juan su padre, y por esta causa es la nobleza deste Rey mucho de loar" (Nieto Soria, J. M., 2015b, p. 113).

Con independencia de su ajuste a la realidad y de la simplificación inherente a los procesos de construcción de la «memoria historiográfica», las connotaciones positivas de la política hacendística y fiscal del monarca recreada en este caso por el cronista eran diversas. Por un lado, la capacidad de Enrique IV para acumular riquezas no habría tenido su origen en un incremento en la tributación lesivo al reino, tal y como ya había defendido Enríquez del Castillo. Por lo tanto, el tesoro conformado se ajustaba a los parámetros éticopolíticos definidos tradicionalmente por la tratadística que censuraban la falta de moderación en la capacidad exactiva del gobernante. ${ }^{34}$ Por otro lado, y frente a la visión aportada por la Crónica incompleta de los Reyes Católicos, el discurso elaborado en la Crónica anónima castellana ponía en valor la figura del monarca, en contraposición a la de su padre Juan II, como forma de resaltar la mejora operada durante los primeros años de su reinado en instrumentos gubernativos que además, habrían permitido al rey poner en práctica virtudes inherentes al oficio regio y al buen gobierno, como la ya señalada liberalidad.

Esta representación de Enrique IV como «monarca liberal», frente a la imagen de prodigalidad o de avaricia presente en la cronística desfavorable, respondía a la necesaria distribución de la riqueza acumulada en fines legítimos y habría tenido reflejo en acciones concretas que resaltaban la labor del rey en defensa de la fe y como protector y benefactor del reino y de aquellos que le servían. Entre estas acciones se destacaban expresamente la reforma y edificación de monasterios patrocinada por el monarca, como la Cartuja de Miraflores de Burgos, el monasterio jerónimo de El Parral de Segovia, y “otros monasterios y logares píos, en cuya reparación mucho[s] de sus thesoros gastó"; la edificación, reforma y reforzamiento de lugares, villas y fortalezas del reino; o el enriquecimiento procurado para muchos criados "haciéndoles merçedes y dándoles haciendas en estos reynos, dotándolos de muchas riquezas como señor e rey de grande ánimo" (Nieto Soria, J. M., 2015b, pp. 113-114).

\subsection{Temor y avaricia: la imagen negativa de la riqueza del rey}

Frente a la valoración positiva del tesoro y la riqueza enriqueños propuesta en estos textos, tanto la Gesta Hispaniensia de Alfonso de Palencia como la anónima Crónica castellanade Enrique IV-que sigue de cerca los planteamientos de Palencia-, marcan un evidente punto de contraste. Como en otras ocasiones, Palencia es el autor que asigna matices más negativos a la acumulación de riquezas llevada a cabo por el monarca como parte del proceso de construcción de un perfil de Enrique IV como «rey monstruoso» del que participa toda su obra. Esta imagen negativa de la riqueza y el tesoro regios ya se pone de manifiesto en un pasaje en el que se abordan los momentos iniciales del reinado, en 1454. Tras relatar la falta de oposición ante el monarca mostrada por aquellos que se sintieron indignados por el frustrado intento de atentado sexual cometido contra Isabel de Portugal, viuda de Juan II, por el maestre de Calatrava Pedro Girón -secundado a decir de Palencia por el propio Enrique IV - el cronista establece una asociación directa entre la capacidad del rey para infundir temor y su poder "asentado en sus inmensas riquezas". La misma asociación de ideas se plantea al aludir Palencia a la administración de los maestrazgos de Santiago y Alcántara vacantes, retenida por el rey, y a los beneficios económicos que sus rentas le procuraban, pues "iba aumentando Enrique sus riquezas, y con ello infundiendo mayor temor a sus desdichados súbditos" (de Palencia, A., 1998, p. 99).

Según este planteamiento la riqueza actuaba como fuerza motriz en la gestación del temor/timor como «emoción política» que empujaba a los súbditos a la obediencia. Dicha emoción estaba dotada en la 
literatura política bajomedieval de connotaciones positivas pues nacía del amor fundado en la razón y la naturaleza, y constituía una de las formas reverenciales de mostrar respeto y humildad, tanto a Dios como hacia el rey. No obstante, en este contexto discursivo, el recurso de Palencia al término timor, empleado en la primera de las citas ${ }^{35}$ y asociado tradicionalmente al miedo filial inspirado por un rey justo, quedaba desfigurado en su sentido original y adoptaba unas connotaciones negativas que permitían su asimilación implícita con la semántica del término metus, entendido como el miedo servil provocado por el tirano y nacido de presiones vinculadas con la posibilidad de pérdida de la integridad física, jurídica o moral de los súbditos ${ }^{36}$.

Por lo tanto, la riqueza del rey y el poder que esta le concedía actuaban, según Palencia, como instrumento de presión tácito. Su mera existencia y exhibición, sin necesidad de recurrir a su uso explícito, limitaba la capacidad reactiva ante actos tan manifiestamente injustos como el intento de violación de Isabel de Portugal, conformando con ello uno de los pilares que habrían sustentado la obediencia inicial mostrada al monarca por sus súbditos. La misma capacidad coactiva asignada a la riqueza enriqueña como manifestación de poder podría deducirse -según narra la Crónica anónima del monarca- de la exhibición intencional de sus joyas y plata en una gran sala del alcázar de Segovia ante los grandes, dispuesta por el rey a comienzos de su reinado, aunque en este caso el cronista no plantea una calificación expresa de la acción en términos políticos o morales. ${ }^{37}$ Mucho más explícito es Fernando del Pulgar, que en la semblanza de Enrique IV incluida en su Crónica de los Reyes Católicos recoge la asociación hecha por Palencia entre riqueza y temor, al señalar que "en los primeros años que reynó, por los muchos tesoros que allegó, fue temido". No obstante, el abandono del rey a sus placeres, la mala administración de la justicia y gobernación del reino, y las dádivas entregadas "sin medida" a sus privados, terminaron provocando según Pulgar el efecto contrario: sus vasallos "le perdieron el miedo" (del Pulgar, F., 1943, p. 21).

Por otra parte, el sentido pernicioso otorgado por Palencia a las "riquezas inmensas" de Enrique IV se hace todavía más patente al comprobar su procedencia. Según el cronista, a la cuantiosa herencia de su madre y las rentas que percibía siendo príncipe, el monarca había sumado otras riquezas cuyo origen podía considerarse reprobable. Por un lado, el monarca se había apoderado del "tesoro acumulado por Álvaro [de Luna], apropiado después de matar a su dueño por su padre” (de Palencia, A., 1998, p. 99). La mención al tesoro del gran privado de Juan II -custodiado en su alcázar de Escalona y del cual en realidad el rey percibió únicamente dos terceras partes tras legar mediante donación un tercio a los herederos del privado (su viuda Juana Pimental y su hijo Juan de Luna) ${ }^{38}$ - no es inocente. La cita apelaba a un hecho bien conocido en Castilla conservado en la memoria literaria e historiográfica (López, C. G., 1992, pp. 259-265; Nieto Soria, J.M., 2017, pp. 504-505) y permitía justificar con un móvil económico, por lo tanto espurio según la doctrina aristotélica que hacía primar la virtud por encima de las riquezas (Díaz Yáñez, M., 2014, pp. 457-458), la supuesta intervención del todavía príncipe Enrique en la operación política que culminó con la decapitación en 1453 de don Álvaro de Luna, para lo cual no habría dudado en utilizar como brazo ejecutor a Juan II.

Por lo tanto, la falta de escrúpulos en la acción descrita -que constituía una manifiesta deformación de la participación del príncipe en la caída en desgracia del privado de su padre- podía identificarse como muestra de avaricia, lo que situaba nuevamente en términos morales la riqueza enriqueña ante una ilegitimidad de origen. Esta apelación a la codicia como forma de justificar el ajusticiamiento de don Álvaro de Luna no fue, sin embargo, un recurso exclusivo de Palencia. La Crónica de don Álvaro de Luna, cuya autoría tradicionalmente se atribuye a Gonzalo Chacón, también achacaba la prisión del Condestable a la avaricia de Juan II por hacerse con sus tesoros y riquezas, apelando a la sentencia de San Pablo (I Tim, 6, 10) que fijaba en la codicia la raíz de todos los males. ${ }^{39}$

La misma ilegitimidad de origen también podía asignarse a la última de las fuentes de recursos económicos del rey descritas en este fragmento por Palencia. Una vez asentado en el trono, Enrique IV habría seguido cobrando "todo lo que el mismo rey [Juan II] había podido agarrar en aquellos pocos días con sus propias artes 
de exacción nuevamente adquiridas", tanto de las rentas de los maestrazgos de Santiago -confiscadas tras la muerte de don Álvaro de Luna- y de Alcántara, retenidas "con igual avaricia” una vez fallecido el maestre Gutierre de Sotomayor (de Palencia, A., 1998, p. 99). La apropiación de las rentas santiaguistas - parte de las cuales ingresaba en la cámara regia, según constata la contabilidad de Arias Dávila de 1460-1462 ${ }^{40}$ - se presenta, además, como una iniciativa adoptada por el rey siguiendo el consejo de su privado Juan Pacheco, marqués de Villena, cuyo objetivo pasaba por ocupar en algún momento la dignidad maestral, tal y como acabaría sucediendo.

De esta forma, el cronista anticipaba con su narración decisiones posteriores como la provisión del maestrazgo santiaguista a Pacheco, realizada en 1467 en un contexto marcado por la división del reino en dos obediencias, situando su origen en apetencias personales supuestamente explicitadas en los momentos iniciales del reinado enriqueño. Era una eficaz forma de guiar al lector de manera teleológica hacia un final inequívoco que respondía a una trama argumental fijada desde el inicio del relato, cuyo móvil se planteaba en este caso en términos marcadamente económicos. La importancia de este planteamiento era máxima, al referirse además a un elemento situado en el centro de la conflictividad política del reinado enriqueño, como la provisión de las rentas santiaguistas y de la dignidad maestral -que Juan II había reservado por cláusula testamentaria para su hijo Alfonso-, utilizado por el grupo de nobles liderado por el marqués de Villena para dar un salto cualitativo en sus demandas al rey, tomando como pretexto la provisión en mayo de 1464 del título de maestre realizada por Enrique IV a su nuevo privado Beltrán de la Cueva (Suárez Fernández, L. 2001, pp. 211-307; Morales Muñiz, M. D. C., 1988, pp. 25-31).

Independientemente de la conflictividad en torno a la provisión del maestrazgo de Santiago, la retención de sus rentas realizada por el rey también respondería a otro objetivo, denunciado por Palencia, que conectaba con la calificación del monarca en términos morales que buscaba trasladar el cronista. Enrique IV habría utilizado estos recursos para "excitar así la codicia de los suyos con cebo puesto en anzuelo, prometiendo uno de los maestrazgos ahora a uno, ahora a otro, fomentando las disensiones y haciendo que todos se disputasen los primeros puestos en su inmunda intimidad" (de Palencia, A., 1998, pp. 99-100). Con ello, la riqueza del monarca mostraba su operatividad como instrumento político canalizado de forma consciente para fomentar la competencia inter-nobiliaria y las disputas en la corte con la pretensión de reforzar la autoridad del rey al situarle como árbitro encargado de determinar el acceso a los resortes del poder, fomentando con ello una falsa fidelidad y servicio al monarca basados únicamente en la promesa futura de beneficios económicos. De esta forma, no solo es que Enrique IV se mostrara codicioso en el disfrute de las riquezas acaparadas, y las utilizara para garantizar la obediencia de sus súbditos nacida del temor/miedo al poder regio que despertaban. Según el cronista, la promesa «simulada» de distribución de estas riquezas, lejos de ajustarse a la práctica de la liberalidad y a los principios inherentes a la justicia distributiva, fomentaba la extensión de la avaricia entre los servidores del rey, diseminando lo que en origen era un comportamiento defectuoso del titular de la dignidad regia a los estratos políticos situados bajo su dependencia.

Por otro lado, la avaricia en la percepción de recursos económicos también era destacada por Palencia al abordar más adelante en su crónica los mecanismos utilizados por el monarca para lograr del Papado la concesión de la bula de indulgencia de cruzada. Se trataba de una cuestión capital para destruir la imagen carismática como «rey cruzado» que habría tratado de edificar el monarca (Echevarría Arsuaga, A., 2004), y justificar las primeras iniciativas opositoras emprendidas por la nobleza. Para ello el cronista construiría un relato que buscaba trasladar una imagen de las campañas contra Granada proyectadas por el rey como ejercicio de simulación destinado a obtener recursos económicos, tal y como ya se había destacado en el memorial de agravios remitido por los nobles al rey en septiembre de 1464 .

En lo que se refiere a las negociaciones sostenidas con el Pontífice, la Gesta Hispaniensia resalta el papel otorgado a los preparativos y al inicio de la primera campaña de 1455 -por ejemplo el limitado reparto de caballos a los grandes "a fin de que los gastos fuesen menores"- como mecanismo de persuasión "para excitar más y más la generosidad del pontífice”, y así justificar la extensión, por primera vez, de la indulgencia 
a los fieles difuntos (de Palencia, A., 1998, p. 104). Con ello, el monarca no habría hecho sino seguir los consejos de su contador mayor Diego Arias Dávila, que en la narración de Palencia desempeña un papel fundamental como inductor y beneficiario de muchas de las medidas fiscales adoptadas por el rey contrarias a la buena gobernación del reino. Además, en el relato de los hechos construido, los consejos de Diego Arias Dávila quedaban vinculados implícitamente a la condición judeoconversa del contador mayor y a su afán por aumentar sus riquezas a través del servicio prestado al monarca, tal y como se señala en el capítulo dedicado a narrar sus oscuros orígenes e "ínfimas inclinaciones" (de Palencia, A., 1998, pp. 57-58). Con ello, se establecía además un nexo directo entre el afán exactivo del monarca y su labor como protector de herejes.

Este afán exactivo ya contaba, según el cronista, con muestras previas. Así se desprende de la acusación formulada contra el rey de permitir abusos en la administración de las ciudades y en la provisión de ordenanzas que protegiesen a su pueblo "con tal de agenciar riquezas para sus favoritos", explicitadas en la práctica del cohecho por parte de los corregidores nombrados por el rey en las ciudades. Se trataba de un aspecto, también criticado en el memorial de los nobles de septiembre de 1464, que resaltaba la permisividad del monarca con prácticas contrarias a la justicia y buen regimiento del reino, entre las cuales se incluía la entrega de dinero a los corregidores por parte de los condenados a muerte como forma de eludir su pena, incentivadas además por Arias Dávila al que se llega a calificar como "jefe de estas exacciones” (de Palencia, A., 1998, pp. 101-102).

De esta manera, las posibles connotaciones positivas asignadas bajo la premisa de un hipotético comportamiento liberal -como el resaltado en su crónica por Diego Enríquez del Castillo-a la distribución de recursos llevada a cabo por el monarca quedaban anuladas por Palencia en función del origen ilegítimo asignado a estas riquezas, contrario además al bien común y la justicia del reino como objeto de especial preservación. A tenor de unos precedentes tan poco ejemplares, Palencia planteaba el consejo dado por el contador mayor al monarca para que hiciese caso omiso a las quejas de sus súbditos y a las murmuraciones de los grandes "ya que tenía dinero en abundancia" con el que costear al incremento en el sueldo de sus tropas de caballería. De nuevo, la riqueza del rey, como recurso político al servicio del buen gobierno, quedaba transmutada en herramienta de presión utilizada contra el reino para laminar cualquier oposición y crítica al monarca.

Este planteamiento servía además al cronista para acreditar la finalidad que supuestamente habría concedido el rey a la guerra contra Granada como instrumento para obtener beneficios económicos y lograr cohesión en torno a una acción gubernativa planteada en términos negligentes. Para ello Enrique IV no habría dudado en seguir las premisas señaladas por Arias Dávila, que habría consolidado además con su consejo el pernicioso ascendiente que tenía sobre el rey. Por un lado, según declaraba el contador mayor, "tanto las querellas del pueblo como las maquinaciones de los magnates levantiscos quedarían acalladas al solo nombre de guerra contra los granadinos". Por otro, "hasta el coste mismo de la campaña podría convertirse en ganancia" siempre y cuando el rey ordenara, amparándose en la guerra contra el emirato nazarí, "nuevos repartimientos personales de impuestos" (en alusión a la solicitud de servicios económicos a las Cortes) y solicitara al papa Nicolás $\mathrm{V}$ la indulgencia para aquellos que contribuyesen a los gastos de las campañas con 15 reales de plata (de Palencia, A., 1998, p. 102).

Más adelante, al relatar las negociaciones sostenidas en 1456 con el papa Calixto III -sucesor de Nicolás $\mathrm{V}$ - para obtener la indulgencia, se vuelve a ratificar el potencial político asignado por el rey al desarrollo de acciones bélicas poco consistentes contra Granada utilizadas "tanto para protegerse de la infamia como para conseguir las ganancias que no dejaba de esperar de la bula de cruzada” (de Palencia, A., 1998, p. 145). Con ello se disfrazaba de apariencia de guerra lo que en realidad no habría sido sino una mera acción propagandística que incluía el despliegue de medios militares. Sus objetivos nunca habrían pasado por arrebatar territorios al infiel, sino por lavar la imagen del rey y obtener recursos económicos apelando como artimaña a una causa impositionis justa y santa dotada de un elevado potencial a la hora de movilizar tanto a las instancias concesionarias como a los contribuyentes, que legitimase el dinero obtenido del reino y del Pontificado. 
En definitiva, este uso ilegítimo de los recursos concedidos no hacía sino resaltar el carácter sacrílego de Enrique IV, contrario a la expansión de la fe cristiana. Además, los recursos empleados en las campañas realizadas ponían de manifiesto la condición del monarca como rex inutilis pues, según señalaba el cronista, "después de gastar en vano sumas y aprovisionamientos inmensos, no se produjo ningún resultado positivo" (de Palencia, A., 1998, p. 111). Como colofón al relato construido, se subrayaban además los beneficios económicos obtenidos por Diego Arias Dávila con cargo a las 800.000 doblas de oro recaudadas en concepto de cruzada de las cuales "nunca se gastó una sola libra en la guerra de Granada" (de Palencia, A., 1998, p. 152). ${ }^{41}$

Si bien la obtención de recursos económicos por parte del rey, justificada en una guerra contra el infiel «simulada», merecía la reprobación más absoluta del cronista, el uso discursivo del tesoro y las riquezas regias que hacen Palencia y el autor de la Crónica anónima en la narración de los acontecimientos posteriores a la deposición en efigie del rey en junio de 1465 volvía a mostrar su potencialidad a la hora de configurar un perfil ético-político de Enrique IV definido entre otros muchos vicios por la avaricia. Todo ello contribuía -junto a los restantes elementos reprobables- a sustentar la legitimidad de su destronamiento. En este sentido, al narrar el intento de mediación entre Enrique IV y el príncipe Alfonso protagonizado en 1465 por el conde de Haro Pedro Fernández de Velasco, tras la división del reino en dos obediencias, tanto Palencia como la Crónica anónima señalan que el noble habría comunicado de manera interesada al monarca depuesto que el final de la contienda solo llegaría "distribuyendo con largueza los tesoros que había exigido y encerrado con avaricia" (de Palencia, A., 1999, p. 345). ${ }^{42}$

De forma complementaria a la caracterización del rey como avariento, la Gesta Hispaniensia también advertía del agotamiento "del gran tesoro guardado en el alcázar de Segovia”, ya que "Enrique, acostumbrado a acumular las riquezas por medio de injustas exacciones, no supo distribuirlas en tiempo de guerra sin desperdiciar con las monedas la poca autoridad que le restaba" (de Palencia, A., 1999, p. 345). Ilegitimidad en el origen de la riqueza acumulada, e incompetencia en su gasto, que ratificaban una vez más la consideración de Enrique IV como rex inutilis. No obstante, según Palencia y la Crónica anónima, la utilidad asignada por el rey a su tesoro como instrumento para garantizar la precaria fidelidad de aquellos que le apoyaban, ya reflejada en la carta enviada por la ciudad de Sevilla al papa en diciembre de 1465 e incorporada en la crónica, se sustentaba en la caracterización moral de los Hispani/castellanos como codiciosos.

Así, el planteamiento táctico defendido en 1465 por el arzobispo de Toledo y el conde de Paredes tras el alzamiento como rey de don Alfonso buscaba vencer sin dilación al monarca depuesto mediante un ataque repentino ante la menor disponibilidad de recursos económicos que tenían los alfonsinos. En este punto el autor de la Crónica anónima recordaba -adaptando la narración de Palencia- que "el favor de los pueblos es mucho mudable e la gente castellana es cobdiçiosa, e como conoscan el grant tesoro quel rey don Enrrique tiene, abriendo la mano, asy los pueblos seguiran a el como a la miel siguen las moscas" (Sánchez Parra, M. P., 1991, p. 166-167). ${ }^{43}$ Con ello, se asignaba a la riqueza regia un uso propagandístico como instrumento de movilización y fuente de adhesión política que, no obstante, Enrique IV no sabría aprovechar. Su inclinación, contraria a comportarse de forma liberal, situaba en una posición ventajosa a los alfonsinos y ofrecía una oportunidad al planteamiento táctico formulado, pues "Enrique no podría hacer frente a un ataque repentino aun si tuviese los tesoros de Midas" máxime teniendo en cuenta que era "lento en gastar riquezas debido a su innata cobardía y avaricia” (de Palencia, A., 1999, p. 341). Por lo demás, el paralelismo trazado entre el monarca y el rey Midas, no hacía sino resaltar la inutilidad del tesoro enriqueño, como inútil le había resultado al rey frigio, según el mito, convertir todo lo que tocaba en oro al haberle impedido esta propiedad alimentarse llevándole a la muerte.

Avariento en la forma de acaparar riquezas y de gastarlas, pero pródigo en la concesión de mercedes como forma de anudar falsas fidelidades, la imagen «bifronte» y contradictoria del monarca presentada por Palencia quedaría matizada por otros autores que hicieron primar el segundo de los vicios señalados en la caracterización moral del rey, por encima de la codicia. Así, Fernando del Pulgar consideraba que la 
prodigalidad del monarca con aquellos que le desobedecían, o con los que le impedían abandonarse a sus deleites, había tenido efectos perniciosos en la administración de la justicia en el reino y en la disipación del patrimonio regio, distribuido y destruido en poco tiempo.

Según Pulgar, a fuerza de conceder mercedes, la obediencia al rey habría terminado por responder únicamente a su condición como fuente de recursos. Además, el excesivo reparto de beneficios "por premio" o "por ofiçio" generaba una dinámica política contraria al buen regimiento del reino que terminaría minando la autoridad del monarca, pues otros "sin temor ni avtoridad alguna tomauan lo que querían", amén de que favorecía el provecho particular en detrimento del bien común. De esta forma el vicio de la prodigalidad retroalimentaba la dependencia política que el rey tenía de la concesión inmoderada de beneficios económicos para asentar su autoridad pues -concluye Pulgar- "los del reyno le tenían por rey para recebir dél mercedes, y no para le servir y obedecer como a su rey". A tenor de este comportamiento, presentado como modelo de mala conducta política, ni "la grandeza de los estados ni de los reynos", ni los tesoros y rentas, ni el miedo al poderío de las huestes, eran recursos suficientes para sostener el estado de los monarcas, si no estaban acompañados de pautas de actuación virtuosas alejadas de deleites y vicios, que favoreciesen el buen juicio para una correcta administración de la justicia, como objeto de especial preservación que permitía a los reyes ser amados y temidos por sus súbditos y conservar sus reinos (del Pulgar, F., 1943, p. 22).

\section{Conclusión}

Tanto la propaganda anti-enriqueña coetánea a la crisis desatada en Castilla en 1464, como la cronística posterior sobre Enrique IV, incorporaron de forma recurrente en su discurso ideas sobre la riqueza y el tesoro acumulados por el monarca. Se trataba en ambos casos de elementos propagandísticos útiles como instrumento de legitimación de la oposición política al monarca y de su posterior destronamiento, en la medida en que permitían elaborar un perfil reprobable del rey susceptible de conectar los fundamentos doctrinales en los cuales se sustentaba la idea de un mal gobierno, por un lado, con algunas de las inquietudes de los gobernados, por otro. En este sentido, hay que tener en cuenta que los elementos de crítica referentes a la riqueza y el tesoro del monarca podían vincularse con aspectos, reales o recreados, de su política hacendísticofiscal (cobro de pedidos y monedas, cruzada y subsidio, alteraciones monetarias, cohecho y venalidad en la justicia) que afectaban o habían afectado materialmente a amplios sectores socio-políticos del reino.

No obstante, los cronistas se encargarían de reelaborar los argumentos contrarios al monarca que apelaban a su riqueza y tesoro, gestados en los inicios de la crisis política desatada desde 1464 y puestos en circulación con el objetivo de generar un clima de «opinión pública» favorable a los sublevados. Para ello, el relato de los hechos construido terminaría amalgamando posteriormente estos argumentos con algunos de los principios teóricos y doctrinales extraídos de la literatura política difundida en la época. De esta forma la riqueza y el tesoro de Enrique IV se convirtieron en puntos de apoyo para sostener la caracterización moral del rey presentada, al tiempo que pasaban a ser considerados como la fuerza motriz, la causa o la consecuencia, de algunos de los comportamientos políticos - positivos o negativos- manifestados por el monarca.

Por un lado, la riqueza y el tesoro del rey, dotados de connotaciones positivas, sirvieron a los cronistas favorables a Enrique IV - caso de Diego Enríquez del Castillo- para elaborar un perfil ético del monarca, que incorporaba la práctica de virtudes como la liberalidad y la magnanimidad, y en el que la notoriedad o "fama" alcanzada por su prestigio y poder, asociada a una "riqueza exhibida", era paralela a la bonanza económica del reino lograda durante los años iniciales de su reinado. Dicho perfil podía mostrar su utilidad a la hora de contrarrestar las críticas contrarias a la política hacendística-fiscal del monarca -en particular la concesión indiscriminada de mercedes como forma de obtener fidelidades- formuladas por sus oponentes. Asimismo, también constituía un argumento eficaz para desacreditar la caracterización moral del rey en términos negativos, bien como codicioso bien como pródigo, planteada por la propaganda anti-enriqueña. 
Por el contrario, la abundante cronística desfavorable al monarca recurrió al uso discursivo de la riqueza y el tesoro del rey, dotados en este caso de connotaciones negativas, como recurso para, por un lado, concretar a partir de elementos plenamente reconocibles por el lector algunos de sus defectos morales y, por otro, poner en evidencia los resultados de una acción política desarrollada de forma deliberada contra el reino y la justicia. Ambas circunstancias conducían irremediablemente a la caracterización de Enrique IV como tirano o rex inutilis, y con ello a legitimar su deposición. El tesoro del rey, manifiestamente ilegítimo en su origen según Alfonso de Palencia, era fruto de la avaricia del monarca. Sobre unas riquezas abundantes el rey había cimentado además la obediencia de sus súbditos basada, por un lado, en el temor servil que generaba un tesoro mal habido, y por otro, en las perspectivas de enriquecimiento personal, contrarias al bien común del reino, que despertaba dicho tesoro en aquellos que le servían. Asimismo, la avaricia y el uso de la riqueza como instrumento político se destacaban como origen de la simulación de la guerra contra el infiel, utilizada por el monarca como pretexto para obtener del reino y del Pontificado recursos económicos con los que atender al enriquecimiento de gentes indignas, como el contador mayor Diego Arias Dávila, entre otros. Al cabo, el uso dado al tesoro tras la deposición en efigie del monarca servía para ratificar el comportamiento avariento de Enrique IV, en unos casos, y pródigo en otros, en la medida en que su dispendio o su falta de gasto respondían únicamente a un afán de perpetuación en el poder, contrario al reino, que habría terminado por socavar las bases de su autoridad.

Con ello quedaba de manifiesto el potencial legitimador/deslegitimador alcanzado por la «riqueza del rey» como instrumento de propaganda particularmente útil en la Castilla del siglo XV a la hora de justificar la lucha política y sus resultados, pero también como topos o lugar común empleado para elaborar una «memoria historiográfica», en este caso sobre la acción gubernativa de Enrique IV, sustentada en la adaptación a este contexto específico del discurso sobre el origen, forma y finalidad de los recursos legados al príncipe por la «comunidad política» elaborado por la reflexión teórica bajomedieval a partir de los principios enunciados por el aristotelismo político.

\section{Bibliografía}

Beceiro Pita, I. (2002). Argumentos ideológicos de la oposición nobiliaria bajo los Trastámaras. Cabiers de linguistique et de civilisation hispaniques médiévales, 25, 211-236. Recuperado de: https://www.persee.fr/doc/cehm_03969045_2002_num_25_1_1238

Bermejo Cabrero, J. L. (1973). Amor y temor al rey (evolución histórica de un tópico político). Revista de Estudios Politicos, 192, 107-128.

Bizzarri, H. Ó. (2002). Avisaçión de la dignidad real. Memorabilia: boletin de literatura sapiencial, 6. Recuperado de h ttp://parnaseo.uv.es/Memorabilia/Memorabilia6/Avisacion.html

Boureau, A. (2006). La religion de l'état: la construction de la republique étatique dans le discours théologique de l'Occident médiéval (1250-1350). París: Les Belles Lettres

Calderón Ortega, J. M. Álvaro de Luna: riqueza y poder en la Castilla del siglo XV. Madrid: Dykinson

Carmona Ruiz, M.A. (2014). La documentación cronística castellana y la opinión pública en Castilla: posibilidades y límites. En H.R. Oliva Herrer, V. Challet, J. Dumolyn, M.A. Carmona Ruiz (Eds.), La comunidad medieval como esfera pública (pp. 211-227). Sevilla: Secretariado de Publicaciones de la Universidad de Sevilla

Carrasco Manchado, A. I. (2010). La memoria del conflicto en la formación de la conciencia política: la visión de Gonzalo Fernández de Oviedo sobre los reinados de Enrique IV y Reyes Católicos. En J. A. Fernández de Larrea y Rojas, y J. R. Díaz de Durana Ortiz de Urbina (Eds.), Memoria e Historia: utilización política en la Corona de Castilla al final de la Edad Media, 221-248. Madrid: Sílex

Carrasco Manchado, A. I. (2006). El rumor político: apuntes sobre la opinión pública en la Castilla del siglo XV. Cuadernos de Historia de España, 80, 65-90. Recuperado de : http://repositoriouba.sisbi.uba.ar/gsdl/cgi-bin/library.cgi?e=d-10000-00---off-0cuahisto--00-2----0-10-0-- 
-0---0direct-10----4------0-11--10-es-Zz-1---20-about---00-3-1-00-00--4----0-0-01-00-0utfZz-8-00\&a=d\&c=c uahisto\&cl=CL2.3\&d=80-22_htm

Carrasco Manchado, A. I. (2001). Enrique IV de Castila: esbozo de una representación de la propaganda política. Orientaciones: revista de homosexualidades, 2, 55-72

Cortes de los antiguos reinos de León y de Castilla (1863-1866). Madrid: Real Academia de la Historia, vols. II y III

Carriazo, J. M. (Ed.) (1940). Crónica de don Álvaro de Luna. Madrid: Espasa-Calpe

Del Val Valdivieso, M. I. (2014). La opinión pública en los núcleos urbanos de la Castilla de fines de la Edad Media: posibilidades de estudio. En H. R. Rafael Oliva Herrer, V. Challet, J. Dumolyn, M. A. Carmona Ruiz (Eds.), La comunidad medieval como esfera pública, pp. 173-191. Sevilla: Secretariado de Publicaciones de la Universidad de Sevilla

Del Val Valdivieso, M. I. (1981). Un motivo de descontento popular: el problema monetario en Castilla durante el reinado de Enrique IV. Historia. Instituciones. Documentos, 8, 151-170.

Díez Yáñez, M. (2014). Las virtudes de la liberalidad, magnificencia y magnanimidad en la tradición aristotélica en España a través de las traducciones al castellano del De regimine principum de Egidio Romano. En C. Esteve (Ed.), El texto infinito. Tradición y reescritura en la Edad Media y el Renacimiento (pp. 449-466). Salamanca: Seminario de Estudios Medievales y Renacentistas-Sociedad de Estudios Medievales y Renacentistas

Echevarría Arsuaga, A. (2004). Enrique IV de Castilla, un rey cruzado. Espacio, tiempo y forma. Serie III. Historia medieval, 17, 143-156. Recuperado de: https://dialnet.unirioja.es/servlet/articulo?codigo $=1262142$

Enríquez del Castillo, D. (1994). Crónica de Enrique IV. A. Sánchez Martín (ed.). Valladolid: Universidad de Valladolid

Estepa Díez, C. (2007). La monarquía castellana en los siglos XIII-XIV. Algunas consideraciones. Edad Media. Revista de Historia, 8, 79-98. Recuperado de: https://dialnet.unirioja.es/servlet/articulo?codigo=2509119

Fernández de Larrea y Rojas, J. A., y Díaz de Durana Ortiz de Urbina, J. R. (Coords.) (2010). Memoria e Historia: utilización politica en la Corona de Castilla al final de la Edad Media. Madrid: Sílex

Foronda, F. (2007): El miedo al rey. Fuentes y primeras reflexiones acerca de una emoción aristocrática en la Castilla del siglo XIV.e-Spania. Revue interdisciplinaire d'études hispaniques médiévales et modernes, 4. doi: https://doi .org/10.4000/e-spania.2273

Gauvard, C. (2008). Qu'est-ce que l'opinion publique avant l'invention de l'imprimerie?. En C. Gauvard, A. Corbin, C. Delporte, J-F. Sirinelli (Eds.), L'Opinion. Information, rumeur, propagande. Le Rendez-vous de l'histoire (pp. 21-5). Nantes: Éditions Pleins

Gauvard, C. (2008). La fama, une parole fondatrice. Médiévales, 24, 5-13. Recuperado de : https://www.persee.fr/doc/medi_0751-2708_1993_num_12_24_1265\#: :text=Gauvard\%20Claude.,La \%20Fama\%2C\%20une\%20parole\%20fondatrice.\&text=La\%20renomm\%C3\%A9e\%2C\%20sous\%20la \%20direction\%20de\%20Claude\%20Gauvard\%20

González Rolán, T. y Saquero Suárez-Somonte, P. (2012). De la Sentencia-Estatuto de Pero Sarmiento a la Instrucción del Relator. Estudio introductorio, edición y notas de los textos contrarios y favorables a los judeoconversos a raiz de la rebelión de Toledo de 1449. Madrid: Aben Ezra Ediciones

González-Ruiz, J. (2017). “¿A cómo vale el ardor / que traéis en vuestra silla?”: otredades no-cristianas, sodomía y propaganda en la corte de Enrique IV de Castilla. eHumanista: Journal of Iberian Studies, 36, 340-352. Recuperado de https://www.ehumanista.ucsb.edu/sites/secure.lsit.ucsb.edu.span.d7_eh/files/sitefiles/ehuman ista/volume36/8R\%20ehum36.glez-ruiz.pdf

Isenmann, E. (1996). Les théories du Moyen Age et la Renaissance sur les finances publiques. En R. Bonney (Dir.), Systèmes économiques et finances publiques (pp. 3-35). Paris: Presses Universitaires de France

Labortie, P. (2010). Opinion publique. En C. Delacroix, F. Dosse, P. Garcia, y N. Offenstadt (Dirs.), Historiographies, II: Concepts e débats, pp. 802-813. Paris: Gallimard

Ladero Quesada, M. Á. (2011). Fiscalidad y poder real en Castilla (1252-1369). Madrid: Real Academia de la Historia, $2^{a} \mathrm{ed}$. 
Ladero Quesada, M. Á. (2009). La Hacienda Real de Castilla (1369-1504). Madrid: Real Academia de la Historia

Ladero Quesada, M. Á. (2005). Capilla, joyas y armas, tapices y libros de Enrique IV de Castilla. Acta historica et archaeologica mediaevalia, 26, 851-874. Recuperado de: https://core.ac.uk/download/pdf/39121871.pdf

Ladero Quesada, M. Á. (1991). 1462. Un año en la vida de Enrique IV, rey de Castilla. En la España medieval, 14, 237-274. Recuperado de: https://revistas.ucm.es/index.php/ELEM/article/view/ELEM9191110237A

Ladero Quesada, M. Á. (1988). El cargo de Diego Arias Dávila en 1462. Espacio. Tiempo. Forma. Serie III. Historia Medieval, 1, 271-293. Recuperado de: https://dialnet.unirioja.es/servlet/articulo?codigo=128946

Ladero Quesada, M. Á. (1982). Moneda y tasa de precios en 1462. Un episodio ignorado en la política económica de Enrique IV de Castilla. En M. Á. Ladero Quesada, El siglo XV en Castilla. Fuentes de renta y politica fiscal, pp. 114-142. Barcelona: Ariel

Ladero Quesada, M. Á., y Cantera Montenegro, M. (2004). El tesoro de Enrique IV en el alcázar de Segovia 1465-1475. Historia. Instituciones. Documentos, 31, 307-352

López, C. G. (1992). La caída y muerte del Gran Condestable de Castilla en el contexto de la literatura de su época. Miscelánea Medieval Murciana, 17, 243-267

Lucca, P. de (1997). On the government of rulers. De regimine principum, J.M. Blythe (ed.). Philadelphia: University of Pennsylvania Press

MacKay, A. (2006). Moneda, precios y política en la Castilla del siglo XV. Granada: Universidad de Granada/ Sevilla: Universidad de Sevilla

MacKay, A (1985). Ritual and propaganda in Fithteenth-Century Castile. Past \& Present, 107(1), 3-43

Martín Rodríguez, J. L. (2003). Enrique IV de Castilla: rey de navarra, principe de Cataluña. Hondarribia: Nerea

Memorias de don Enrique IV de Castilla. Vol. II. Colección documental (1835-1913). Madrid: Real Academia de la Historia

Morales Muñiz, M. D. C. (1988). Alfonso de Ávila, rey de Castilla. Ávila: Diputación Provincial de Ávila-Institución Gran Duque de Alba

Nieto Soria, J. M. (2019). Fundamentos de legitimación impositiva en el origen de las asambleas representativas de Castilla. En C. Laliena, M. Lafuente, Á. Galán (Eds.), Fisco, legitimidad y conflicto en los reinos hispánicos (siglos XIII-XVII) (pp. 93-114). Zaragoza: Prensas de la Universidad de Zaragoza

Nieto Soria, J. M. (2013). Entre los derechos de la Corona Real y los deberes de la liberalidad del príncipe. En Á. Galán Sánchez y J. M. Carretero Zamora (Eds.), El alimento del Estado y la saludad de la república: origenes, estructura $y$ desarrollo del gasto público en Europa (siglos XIII-XVIII), pp. 97-114. Madrid: Instituto de Estudios Fiscales

Nieto Soria, J. M. (2015a). Memoria histórica: el rescate interesado del pasado. En E. López Ojeda (Ed.), Nuevostemas, nuevas perspectivas en historia medieval: XXV Semana de Estudios Medievales (Nájera, 28 de julio al 1 de agosto de 2014), pp. 159-182. Logroño: Instituto de Estudios Riojanos

Nieto Soria, J. M. (2015b). De Enrique IV al emperador Carlos. Crónica anónima castellana de 1454 a 1536. Madrid: Sílex

Nieto Soria, J. M. (2005). Rex inutilis y tiranía en el debate político de la Castilla bajomedieval. En F. Foronda, J. P. Genet, y J. M. Nieto Soria (Eds.), Coups d'État à la fin du Moyen Âge? Aux fondements du pouvoir politique en Europe occidentale (pp. 73-92). Madrid: Casa de Velázquez

Nieto Soria, J. M. (1988). Fundamentos ideológicos del poder real en Castilla (siglos XIII-XV). Madrid: Ediciones de la Universidad Complutense

Nogales Rincón, D. (2018). Predicación y comunicación política en la Corona de Castilla (1369-1516). En J. M. Nieto Soria y Ó. Villarroel González (Eds.), Comunicación y conflicto en la cultura politica peninsular. Siglos XIII al XV (pp. 263-294). Madrid: Sílex Ediciones

Nogales Rincón, D. (2017). Pedro de Chinchilla. Carta y breve compendio. Exhortación o información de buena y sana doctrina. Introducción, edición y notas. Valencia: Publicacions de la Universitat de València 
Ohara, S. (2005). Reflexiones sobre la difusión de la información política en el ámbito urbano durante el reinado de Enrique IV. Historia. Instituciones. Documentos, 32, 247-262. Recuperado de: https://dialnet.unirioja.es/servle t/articulo?codigo $=2903868$

Ohara, S. (2002). La propaganda en la guerra sucesoria de Enrique IV (1457-1474). Edad Media. Revista de historia, 5, 117-133. Recuperado de: https://dialnet.unirioja.es/servlet/articulo?codigo $=625751$

Ortego Rico, P. (2020a). Riqueza, liberalidad y bien común: legitimidad y memoria política del tesoro real en Castilla (siglos XIII-XV). Anuario de Estudios Medievales, 50(1), 293-321

Ortego Rico, P. (2020b). La política monetaria de Enrique IV de Castilla en la antesala de la guerra civil: causas y consecuencias económicas y políticas (1454-1465). En J. I. Fortea Pérez y R. Lanza García (Eds.), Fisco y moneda. El uso del dinero y las economías urbanas en los reinos hispanos, siglos XIV-XVIII (pp. 119-192). Santander, Servicio de Publicaciones de la Universidad de Cantabria.

Ortego Rico, P. (2018). Propaganda, fiscalidad e ideal cruzadista durante el reinado de Enrique IV de Castilla. Hispania sacra, 70(141), 237-266. Recuperado de: https://dialnet.unirioja.es/servlet/articulo?codigo $=6691873$

Ortego Rico, P. (2015). Poder financiero y gestión tributaria en Castilla: los agentes fiscales en Toledo y su reino (1429-1504). Madrid: Instituto de Estudios Fiscales

Ortego Rico, P. (2009). Justificaciones doctrinales de la soberanía fiscal regia en la baja Edad Media castellana. En la España Medieval, 32, 113-138. Recuperado de: https://dialnet.unirioja.es/servlet/articulo?codigo=3121037

Palencia, A. de (1999). Gesta Hispaniensia ex annalibvs svorvm diervm collecta. Tomo 2. Libri VI-X. B. Tate y J. Lawrance (Eds.). Madrid: Real Academia de la Historia

Palencia, A. de (1998). Gesta Hispaniensia ex annalibus svorvm diervm collecta. Tomo 1. Libri I-V. B. Tate y J. Lawrance (Eds.). Madrid: Real Academia de la Historia

Paolini, D. (2008). Las Coplas de Mingo Revulgo: estudio preliminar, edición crítica y notas. Salamanca: Ediciones Universidad de Salamanca

Pulgar, F. del (1943). Crónica de los Reyes Católicos. Volumen primero, J. M Carriazo y Arroquia (Ed.). Madrid: EspasaCalpe

Puyol, J. (1934). Crónica incompleta de los Reyes Católicos. Madrid: Real Academia de la Historia

Sánchez Parra, M. P. (Ed.) (1991). Crónica anónima de Enrique IV de Castilla. 1454-1474 (Crónica castellana) (Tomo II. Crónica). Madrid: Ediciones de la Torre

Satorre, J. J. (1980). "La novela moral de Graçián. Un texto inédito del siglo XV”. Estudios Lulianos, 24, 165-210

Satorre, J. J. (1981-1983). “La novela moral de Graçián (continuación)”, Estudios Lulianos, 25, 83-165

Scordia, L. (2005). "Le roi doit vivre du sien”. La théorie de l’impôt en France (XIIIe-XVe siècles). Paris: Institut d’Études Augustiniennes

Scordia, L. (2000). L’exégèse de Genèse 41. Les sept vaches grasses et les sept vaches maigres: providence royale et taxation vertueuse (XIIIe-XIVe siècles). Revue des Études Augustiniennes, 46, 93-119

Suárez Fernández, L. (2001). Enrique IV de Castilla. La difamación como arma politica. Barcelona: Ariel

Triano Milán, J. M. (2018). La llamada del rey y el auxilio del reino. Del pedido regio a las contribuciones de la Santa Hermandad (1406-1498). Sevilla: Universidad de Sevilla

Valera, D. de (1878). Epistolas de mosén Diego de Valera enbiadas en diversos tiempos e a diversas personas. Madrid: Sociedad de Bibliófilos Españoles

\section{Notas}

1 Este trabajo forma parte de los siguientes Proyectos de Investigación: "La construcción de una cultura fiscal en Castilla: poderes, negociación y articulación social (ca. 1250-1550)” (PGC2018-097738-B-100), “Circuitos financieros, crecimiento económico y guerra (siglos XV-XVI)" (UMA18-FEDERJA-098) y "Expresiones de la cultura política peninsular en las relaciones de conflicto (Corona de Castilla, 1230-1504)" (HAR2016-76174-P), integrados en la Red Arca Comunis (http://www.arcacomunis.uma.es). 
2 Sobre la fundamentación doctrinal de la capacidad exactiva del monarca ver J. M. Nieto Soria (1988) y P. Ortego Rico (2009). La retórica política utilizada en el siglo XIII en el contexto de las asambleas representativas castellanas ha sido estudiada por J. M. Nieto Soria (2019).

3 Sobre el proceso de extensión y consolidación de las atribuciones fiscales de los monarcas castellanos durante la baja Edad Media ver, sin ánimo de ser exhaustivo, M. A. Ladero Quesada (2011; 2009) y las reflexiones de C. Estepa Díez (2007).

4 Además de los contenidos referidos a las prácticas tiránicas vinculados con la exacción inmoderada, incluidos en la Segunda Partida, el Libro de los cien capitulos y la Suma de la Política de Sánchez de Arévalo, analizados en estos trabajos, la Avisaçión de la dignidad real incluye entre las condiciones del tirano que "a todos trabaja por fazer pobres" (Bizzarri, H.Ó., 2002).

5 Sobre las posibilidades y límites de aplicación del concepto de «opinión pública» al período medieval ver P. Labortie (2010) y C. Gauvard (2008). Para el ámbito de Castilla ver, entre otros, los trabajos de M. I. Del Val Valdivieso (2014); M. A. Carmona Ruiz (2014) y A. I. Carrasco Manchado (2006).

6 Aplicación del concepto de memoria al análisis de la baja Edad Media castellana ver J. A. Fernández de Larrea y Rojas, y J. R. Díaz de Durana y Ortiz de Urbina (2010).

7 Además de los pasajes de la crónica de Pedro I del Canciller Ayala en los que se recrea la conformación del tesoro del monarca, las dos cartas enviadas teóricamente por Ibn al-Jatib al rey don Pedro, e incluidas en la crónica ayalina como forma de justificar el asesinato del monarca con la finalidad de legitimar el acceso al trono de su hermanastro Enrique II, también se refieren como elemento de crítica a la acumulación de riquezas por parte del rey (Ortego Rico, P., 2020a, pp. 308-312).

8 "Otrossy alo que nos dixieron que por quanto la tierra estaua muy pobre e menesterosa e despoblada, por los grandes pechos e tributos queles fazia pagar aquel malo tirano que se llamaua Rey [...]". (Cortes de los antiguos reinos de León y de Castilla, vol. II, pp. 145-146).

9 Sobre el reinado de Enrique IV, y particularmente en lo referido a los planteamientos fácticos, son imprescindibles los trabajos de L. Suárez Fernández (2001) y J. L. Martín Rodríguez (2003).

10 El estudio de la propaganda desplegada durante el reinado de Enrique IV, con particular énfasis en los componentes políticos asociados al ritual de deposición del monarca realizado en Ávila en junio de 1465, y su vínculo con textos eminentemente propagandísticos como las Coplas de Mingo Revulgo, fue analizado por A. MacKay (1985). Ver también los estudios de A. I. Carrasco Machado (2001) y J. González-Ruiz (2017), entre otros.

11 El vínculo entre la "despersonalización" de los bienes del monarca y la incorporación del "bien común" -bajo distintas formulaciones- como causa final de la imposición, ha sido puesto de manifiesto por J. M. Nieto Soria (1988. pp. 146-147) y P. Ortego Rico (2009, p. 121).

13 La utilización política de las medidas monetarias adoptadas por el rey ha sido analizada por M. A. Ladero Quesada (1982); M. I. Del Val Valdivieso (1981); A. Mackay (2006) y P. Ortego Rico (2020b).

14 "También vos fago saber que todo el dinero e tesoro que tenia ayuntado en la cibdad de Segovia, lo ha ya todo gastado e despendido que sola una blanca no le queda, salvo alguna plata de que agora fase reales de muy baja ley e casi falsos para pagar sueldo e sostener la gente, pero nin aun aquello basta para lo poder sostener de aquí e Navidad en ninguna manera, segund la contía que ello es e las grandes debdas que debe, asi de sueldo como de los acostamientos. Ves que miraglo de nuestro Señor, que como estos tesoros fueron mal ganados, adqueridos e ayuntados de los pedidos e monedas que pagaban los pobres labradores e miserables personas, e de las crusadas e subsidios otorgados por los Santos Padres para la guerra de los moros, e de los robos e cohechos e estorsiones fechos a muchos cibdadanos destos mis regnos e aun a caballeros e fijosdalgo asas por maneras e colores esquesitas, e aun la justicia fué vendida e cambiada por el dicho mi adversario e por sus ministros e oficiales muchas veces por dinero: e los oficios de corregimientos e los oficios de las alcaldías e regimientos e juraderías e escribanías e otros oficios que pocos o ningunos quedaban que no fuesen vendidos, todo es ya gastado e despendido sin ningund provecho e utilidad suya" (Memorias de don Enrique IV 1835-1913: doc. CXXIX, 516).

15 La misiva señalaba textualmente que el monarca "exigió servicios para combatir a los moros, y despojó así de sus riquezas a los cristianos para enriquecer a los sarracenos" (de Palencia, A., 1999, p. 310).

16 Los mecanismos de difusión de la propaganda política durante el reinado de Enrique IV han sido analizados por S. Ohara (2002; 2005).

17 Sobre el concepto aristotélico de liberalidad, abordado en el libro IV de la Ética a Nicómaco, y muy presente en la tratadística política bajomedieval ver M. Díez Yáñez (2014). La presencia de la liberalidad en el discurso político-fiscal de la Castilla bajomedieval ha sido estudiada por J. M. Nieto Soria (2013).

18 Desde un punto de vista metodológico y conceptual, para abordar el tema de la memoria histórica, son imprescindibles las puntualizaciones realizada por J. M. Nieto Soria (2015a). Son también de particular interés las consideraciones realizadas a partir del estudio de la obra de Gonzalo Fernández de Oviedo por Carrasco Machado, A. I., 2010, p. 221-248. Se insiste en el papel que la memoria elaborada a partir de vivencias personales podía tener como elemento de aprendizaje y muestra de "auto-conciencia" de lo político. 
19 Diego Enríquez del Castillo (1994) señala, tras narrar la toma de Segovia en septiembre de 1467 por parte de los partidarios del infante-rey don Alfonso en el contexto de la guerra civil motivada por la división del reino en dos obediencias -enriqueña y alfonsina- tras la deposición del monarca en junio de 1465, que Enrique IV tenía en esta ciudad "todos sus tesoros que sin dubda fueron muchos y en gran cantidad de diversas rriquezas, que yo sin dubda vi muchas vezes” (p. 288).

20 Sobre los recursos de la «cámara» del rey y los pagos a ella vinculados en 1462 ver M. A. Ladero Quesada (1991). Las joyas, tapices, ornamentos de la capilla y libros del monarca en M. A. Ladero Quesada (2005). La composición del tesoro enriqueño y su enajenación a partir de 1465, en el contexto de la guerra civil posterior a la división del reino en dos obediencias tras la desposición en efigie del monarca, en M. A. Ladero Quesada y M. Cantera Montenegro (2004).

21 Sobre los servicios en forma de "pedidos" y "monedas" otorgados por las Cortes durante el reinado de Enrique IV y sus motivaciones ver el análisis de J. M. Triano Milán (2018, pp. 213-242).

22 Archivo General de Simancas, Escribanía Mayor de Rentas, leg. 16, f. 8.

23 El desvío de fondos de la cruzada y el subsidio a fines alejados de la guerra de Granada, y la intervención de Diego Arias Dávila como receptor de abultadas sumas procedentes de estos recursos se analiza en M. A. Ladero Quesada (1988, pp. 279-280) y P. Ortego Rico (2018, pp. 254-259).

24 Sobre los diversos significados de la palabra "fama", su vinculación con lo público, y su afinidad con el rumor y la opinión ver C. Gauvard (1993, pp. 5-13) y A. I. Carrasco Manchado (2006, pp. 66-67).

25 L. Scordia (2005) considera que la reflexión sobre el fasto del estado regio evolucionó de manera radical desde una desconfianza inicial, pasando por el respeto y la justificación, hasta llegar a plantearse en términos de necesidad política.

26 Cabe recordar que la imposición virtuosa debía ajustarse a cuatro causas: la causa eficiente (que define la instancia con capacidad para establecer un tributo), la causa final (asociada con la legitimidad del destino concedido al tributo), la causa formal (la medida adoptada por la carga) y la causa material (la base imponible). Ver desde un punto de vista general E. Isenmann (1996) y L. Scordia (2000).

27 En el caso castellano, la posibilidad del príncipe para tener un tesoro era aceptada por Rodrigo Sánchez de Arévalo en su Suma de la Política, como condición ineludible para sostener guerras. Por su parte, Fernando de la Torres, en su Libro de las veynte cartas e quistiones (1449) defendía la capacidad de tesaurización del monarca "en quantía razonable segúnd la facultad del reyno" para el uso de estos recursos en la guerra, aunque también para afrontar los gastos ordinarios. Finalmente, un diccionario eclesiástico de mediados del siglo XV defendía la posibilidad de que los reyes dispusiesen de recursos tesaurizados para garantizar la paz de los súbditos y la defensa del reino frente a los adversarios (Ortego Rico, P., 2020a, p. 215).

28 "Fue tan grande su franqueza, tan alto su coraçón, tan alegre para dar, tan liberal en conplillo, que de las merçedes hechas nunca se rrecordava, ni dexó de las hazer, mientras estuvo prosperado" (Enríquez del Castillo, D., 1994, pp. 134-135).

29 Estas críticas se manifestaron con gran rotundidad, por ejemplo, durante las Cortes de Ocaña de 1469 en cuyo transcurso los procuradores solicitaron la revocación de las mercedes concedidas por el rey desde el 15 de septiembre de 1464 (fecha de inicio de la crisis política del reinado). En su respuesta, el monarca aplazaba la revocación de estas mercedes argumentando frente a los procuradores que "commo vedes no soy salido de todo punto de la dicha nesçesidad y menester” que le había llevado a concederlas. (Cortes de los antiguos reinos de León y de Castilla, vol. III, pp. 773-786).

30 “ $\mathrm{O}$ rreyes poderosos que sosjuzgáys los inperios! ¡O prínçipes tenporales que señoreáys al mundo! Tomad agora enxenplo en la pujança de este rrey, quando començó a rreynar; sean vos espejos sus altos triunfos que le dió la fortuna, su franca libertad, sus piadosas obras, su mucha clemençia con que sojuzgó e governó sus súbditos. Y mira que, ni lo vno lo libró de su falsa presunçión de sus traydores criados, ni lo al lo escapó de la muerte, que lo privó de sus rreynos y despojó del señorío. Sy primero se vió con gloriosa fama, los suyos se la rrobaron y quedó desonrrado. Si fue señor de grandes tesoros, aquellos lo enpobreçieron. Sy ganó muchas tierras, sy provinçias algunas se alçaron por él, aquellos, como yngratos, se las hizieron perder. Ellos, rresçibiendo merçedes, se tornaron peores; él, sufriendo sus injurias syenpre, se hizo mejor. E ansi fenesçió su vida con mucha paçiençia, acabaron sus días con poco descanso, salieron sus carnes de los travajos mundanos, rreposa su espíritu de tantos afanes y duermen sus huesos sin verse corridos. Pues, sy discreçión e saber alcançáys, si seso y prudençia tenés vosotros, los del cetro rreal, contenplad su próspero estado, su graçiosa vmanidad, sus merçedes infinitas, sus graves persecuçiones, sus trabajos, afanes, sus desmedidas fatigas, y veréys que, ni la mucha potençia, vos deve cabsar sobervia; ni las sobradas rriquezas, hazer avarientos; ni los casos desastrados, privar de la virtud; ni las fieras adversydades, enajenar el coraçón de la condiçión rreal" (Enríquez del Castillo, D., 1994, p. 399).

31 El vínculo entre la riqueza del príncipe y la virtud de la magnanimidad tenía una larga tradición. Por ejemplo, el capítulo 7 del libro 2 del De regimine principum de Tolomeo de Lucca ya vinculaba la posesión de riquezas artificiales por parte del príncipe con el sostenimiento de la magnanimidad, en la medida en la que la práctica de esta virtud implicaba implica fuertes dispendios (P. de Lucca, 1997, pp. 117-120).

32 Por ejemplo, en Mateo 5, 45 se señala que "Dios hace llover sobre justos e injustos".

33 Los fundamentos religiosos del pago de rentas al monarca por parte de sus súbditos tiene evidentes reminiscencias bíblicas. Según la doctrina paulina del tributo (Rom 13, 1-7 y I. Tim. 2, 1-2), para que el soberano pudiera cumplir 
su oficio, preservar la paz y el orden interno, y defender su reino de amenazas exteriores, sus súbditos debían poner a su disposición los medios necesarios. Dicha idea encontraría eco en algunos sermones castellanos, surgidos al calor de conflictos sociales en los que se puso en cuestión la autoridad del poder regio, muy explícitos al traer a colación la teoría paulina del impuesto como forma de resaltar el vínculo entre tributación y obediencia. Es el caso del Sermo in die beati Agustini, predicado a instancias de Juan II tras la revuelta anticonversa de Toledo en Valladolid en agosto de 1449. Dicho sermón incidía en la obligatoriedad del pago de tributos como signo de obediencia al rey en calidad de servidor de Dios, apoyada en el comentario de la Epistola a los Romanos (González Rolán, T., Saquero Suárez-Somonte, P., 2012 , pp. 74-75). Todo ello formaba parte de la crítica hacia la desobediencia y el ataque al rey en el contexto de la rebelión toledana anticonversa, y del objetivo general de la homilía, que no era otro que la exhortación a la paz y el combate contra la soberbia. Análisis de este sermón desde este punto de vista en D. Nogales Rincón (2018, pp. 290-291).

$34 \mathrm{La}$ moderación en el ingreso y en el gasto eran principios propios de la tradición aristotélica, ya presentes en textos castellanos del siglo XIII como el De preconiis Hispanie de fray Juan Gil de Zamora, el Secretum Secretorum o la Poridat de Poridades, o el Libro de los cien capitulos. Posteriormente los mismos principios aparecen en obras del siglo XV como la Suma de la Política de Rodrigo Sánchez de Arévalo o la Istoria de las bienandanzas e fortunas de Lope García de Salazar, entre otras (Ortego Rico, P., 2020a, pp. 306-307).

35 Tantum flagitium tamen aegerrime tulerunt ii qui pura mente facinus animaduertebant; sed timorem inferebat potentia regis freta exuperantissimis opibus (de Palencia, A., 1998, p. 99).

36 La diferencia entre timor y metus, y su uso político, ha sido analizado por J. L. Bermejo Cabrero (1973, pp. 107-128) y F. Foronda (2007). Sobre el vínculo entre la riqueza del príncipe y la creación de emociones políticas como el temor y el amor ver L. Scordia (2005, pp. 339-341).

37 "E de ally el rey se partio para la çibdat de Segovia, donde quiso que fuesen con el los dichos señores [e con ellos] el almirante don Fadrique que ende estava, e todos los otros grandes que por estonçe en la corte se fallaron, a los quales el rey mando que viesen las lavores que fazia enel Alcazar de aquella cibdat, e mostroles sus joyas e plata, lo qual todo mando poner en una gran sala; e podria aver en la plata labrada de diversas formas fasta doze mill marcos, e allende desto avia algunas pieças de oro en que podria aver fasta dozientos maros, syn las joyas de gran valor que ally les mostro asy en joyeles como en [collares] guarnidos de piedras e perlas" (Sánchez Parra, M. P., 1991, p. 25).

38 La conformación y contenidos del tesoro de don Álvaro de Luna han sido analizados por J. M. Calderón Ortega (1998, pp. 284-292).

39 "La cobdicia, segúnd lo dize el apóstol Sant Pablo, es raíz de todos los males. El Rey, aunque por muchos de los sus reynos era tenido por franco e por dadivoso, pero por çierto que quien bien le conosçía en otra posesión le tenía. Mas como aquello non sea de la presente Historia deberlo proseguir, torna al intento suyo. Así fué que el Rey, después que ya tovo preso al su leal Maestre, no mereçedor por çierto de la tal prisión, cobdiçiando aver sus thesoros e riquezas, ca algunos fueron que dixeron aquella aver seydo la principal cabsa de su prisión, e porqué su voluntad se trastornó contra el mismo Maestre, enbió luego aquella noche después de pasado el día en que el Maestre fué preso por Gonçalo Chacón, a la cárcel donde estaba. E venido ante él, poniéndole el Rey non pequeños miedos, demandóle que le dixesse de las riquezas e tesoros e de las escripturas del Maestre" (Carriazo, J. M., 1940, pp. 410-411).

40 El cargo o ingreso del contador mayor del rey Diego Arias Dávila, como receptor de diversas cantidades en nombre del monarca, incluye $156.050 \mathrm{mrs}$ en 1460, $493.717 \mathrm{mrs}$ en 1461 -único año completo de la contabilidad-y $190.000 \mathrm{mrs}$ en 1462. Las cantidades probablemente responden a un aprovechamiento del $10 \%$ de las rentas santiaguistas destinado a la cámara del rey (Ladero Quesada, M. A. 1988, p. 280).

41 El autor de la Crónica anónima de Enrique $I V$, aunque obvia la implicación de Diego Arias Dávila en la supuesta malversación de los caudales recaudados en concepto de cruzada, sí señala que de su rendimiento "muy poca parte se gastó en la guerra de los moros, de lo qual todos los grandes del reyno fueron mucho turbados” (Sánchez Parra, M. P., 1991, p. 66).

42 La Crónica anónima es completamente subsidiaria en la narración del mismo pasaje (Sánchez Parra, M. P., 1991, p. 170).

43 Se adapta en este caso un pasaje de la crónica de Palencia, que señala que "si se dejase correr el tiempo sin oprimir con repentino asedio al más opulento de los reyes, se le daría ocasión excelente para hacer la guerra con dinero, y los españoles, demasiado ansiosos de mayores salarios, se cernirían sobre la hacienda de Enrique como las moscas a la miel" (de Palencia, A., 1999, p. 341). 